This dissertation has been

microfilmed exactly as received

69-8594

FADULU, Sunday Olufunmilola, 1940-

BIOCHEMICAL CHARACTERIZATION AND SKIN

TEST SENSITIVITY OF MYCELIAL GROWTH

FILTRATE OF HISTOPLASMA DUBOISII.

The University of Oklahoma, Ph.D., 1969

Microbiology

University Microfilms, Inc., Ann Arbor, Michigan 


\title{
THE UNIVERSITY OF OKLAHOMA GRADUATE COLLEGE
}

\section{BIOCHEMICAL CHARACTERIZATION AND SKIN TEST \\ SENSITIVITY OF MYCELIAL GROWTH FILTRATE \\ OF HISTOPLASMA DUBOISII}

\author{
A DISSERTATION \\ SUBMITTED TO THE GRADUATE FACULTY \\ in partial fulfillment of the requirements for the \\ degree of \\ DOCTOR OF PHILOSOPHY
}

BY

SUNDAY OLUFUNMILOLA FADULU

Norman, Oklahoma

1969 


\section{BIOCHEMICAL CHARACTERIZATION AND SKIN TEST \\ SENSITIVITY OF MYCELIAL GROWTH FILTRATE OF HISTOPLASMA DUBOISII}

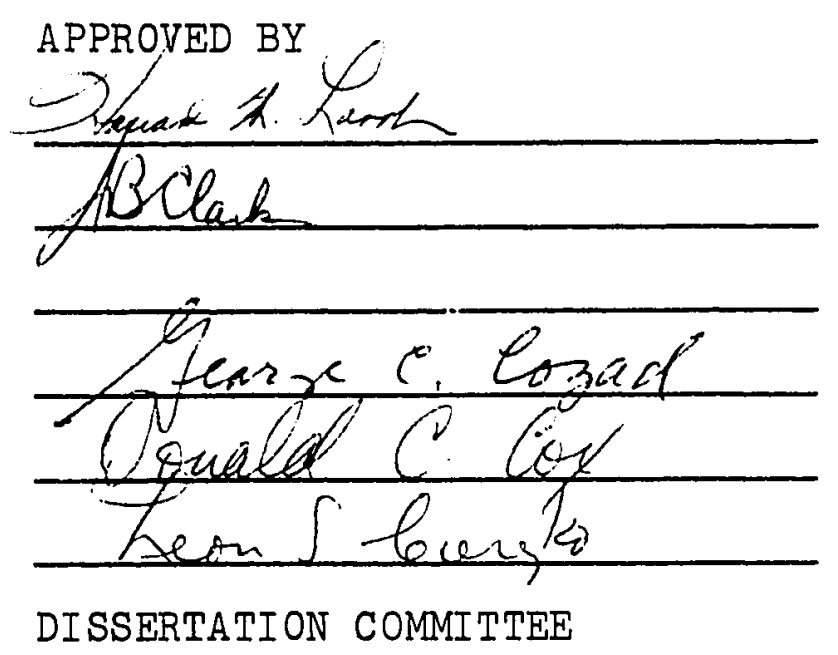




\section{ACKNOWLEDGMENT}

The author wishes to express sincere gratitude to Dr. Howard $W$. Larsh for his suggestions and assistance in the supply of all the materials and equipments used in this study. The Consulate General of Nigeria has directed me to express sincere appreciation to Dr. Howard W. Larsh.

Sincere appreciation to Drs. G. C. Cozad, J. B. Clark, Donald Cox, and Peter A. Bartels for their assistance in the writing of this manuscript; and to the members of my dissertation committee. Also to $\mathrm{Dr}$. W. Sorenson for his assistance in the development and printing of the photographs.

A special note of appreciation is extended to Mr. J. C. Smith, Mr. Don Wiggins, Miss A. Robinson, and Mrs. Sharon Harris for their technical assistance in this study.

The author wishes also to express sincere gratitude to the Federal Government of Nigeria, as a Federal Nigerian Scholar, for the award of the scholarship which afforded this opportunity.

A special thank you to Jackie for typing the manuscript. 
TABLE OF CONTENTS

Page

LIST OF TABLES

$\mathrm{v}$

LIST OF ILLUISTRATIONS. . . . . . . . . . .

vi

INTRODUCTION . . . . . . . . . . . .

MATERIALS AND METHODS. . . . . . . . . . .

RESULTS. . . . . . . . . . . . . . .

DISCUSSIONS.

49

SUMMARY AND CONCLUSIONS.

57

BIBLIOGRA PHY . . . . . . . . . . . . .

59 


\section{LIST CF TABLES}

Table

Page

1. List of (Organisms) Isolates used . . . .

2. Experimental infection of guinea pigs . . .

3. Smith's Asparagine Synthetic Medium . . . .

4. Preparation of Crude Mycelial Growth Filtrate. . . . . . . . . . . 14

5. Sensitization and Skin Testing Schedule . . 17-19

6. Stock Solution for Anionic Gel System . . . 22-23

7. Skin Test Results with different dilution of the crude filtrate... . . . 39-40

8. Skin Test Reactivity to Homologous and Heterologous antigen. . . . . . . . . 


\section{IIST OF ILIUSTRATIONS}

Figure

Page

1. . duboisii culture in asparagine medium showing white matted colonies. . . . . .

2. H. duboisii infected guinea pigs with

3. Histopathological sections of tissues of guinea pigs infected with $\mathrm{H}$. duboisii yeast cells and mycelial fragments. . . . . . . . . . . .

4. Immuno-diffusions and immuno-electrophoretic patterns of mycelial filtrates of $\underline{H}$. duboisii and $\underline{H}$. capsulatum with serum of guinea pigs infected with H. duboisii and $\underline{H}$. capsulatum. . . . . .

5. Chromatogram of partially purified culture filtrate of $\mathrm{H}$. duboisii

6. Changes in total protein, total carbohydrate, and reducing sugars during a 6 month incubation period of $\underline{H}$. duboisii 2100.. . . . . . . . . . . .

7. Mean skin test reaction of crude mycelial filtrate of $\underline{H}$. duboisii 210 . .

8. Changes in total protein, total carbohydrate, and reducing sugars during a 6 month incubation period of $\underline{H}$. duboisii 210 .............

9. Mean skin test reaction of crude mycelial filtrate of $\mathrm{H}$. duboisii 2100 ... . . .

10. $\mathrm{pH}$ readings of mycelial growth filtrates of $\underline{H}$. duboisii 2100 and $\underline{H}$. duboisii 210 . . 
11. Electrophoretic patterns of crude mycelial growth filtrates of $\mathrm{H}$. duboisii 210 and their corresponding microdensitometer tracings...............

12. Electrophoretic patterns of crude mycelial growth filtrates of $\underline{H}$. duboisii 2100 ( 1 wk-12 wks), and their corresponding microdensitometer tracings . . . . . . .

13. Electrophoretic patterns of crude mycelial growth filtrates of $\underline{H}$. duboisii 2100 (16 wks-24 wks), and their corresponding microdensitometer tracings . . . . . . .

14. Electrophoretic patterns of crude mycelial growth filtrates of $\underline{H}$. duboisii 210

( 16 wks-24 wks), and their corresponding microdensitometer tracings . . . . . . . 


\section{BIOCHEMICAL CHARACTERIZATION AND SKIN TESQT SENSITIVITY OF MYCELIAL GROWTH FILTRATE OF HISTOPLASMA DUBOISII}

\section{INTRODUCTION}

Bablet, in 1947, described histoplasmosis as a "disease of the future." (41). Originally described by Darling (11) in the Panama Canal Zone in 1906, it was believed by him to be a disease of Tropical America, but in intervening years only two additional cases were reported from the Caribbean area, one from Honduras in 1926, and the other from Columbia. (43). Histoplasmosis has been shown to be widespread, cases having been reported from many countries throughout the world. In a 1945 review, only 71 reported cases of Histoplasmosis could be found in literature, and 10 years later 30 million Americans were estimated to have, or to have had the infection. (26). The basis for this radical change lies in the use of the skin test antigen, histoplasmin, as an epidemiologic tool to determine the pattern of the disease, to delineate new cases, and to aid in the study of suspected cases. $(29,2)$. Although for many years this disease was considered to be 
uniformly fatal, recent evidence has shown that the pulmonary form exists with only mild clinical manifestation or even as a subclinical infection (43).

In addition to the classical types of histoplasmosis, a different type of histoplasmosis occurs in Africa (2). Despite the similarities of the mycelial form of the fungus to that of Histoplasma capsulatum, Vanbreuseghen considered the African strain a new species and named it Histoplasma duboisii $(52,53)$. His description of $\underline{H}$. duboisii as a new species was based on the morphological difference of the yeast form in the tissue. In this disease the fungus cells in the tissue were found to be extremely large. These are ovoid and 10-13.5u in diameter. They have thick walls and contain one or more fat globules $(41,53)$. They were also characterized by the development of papules, sometimes resembling those of molluscum contagiousum which may lead to ulceration. Lesions were often associated with ganglia and bone (30). In 1964, a radiological finding in the infection of $\underline{H}$. duboisii revealed ribs and spinal involvement. (7).

In 1953, Clarke, et al., reported a new case of African Histoplasmosis and concluded that it was a distinct entity (53). Schwarz and Drouhet reported, in animal inoc-

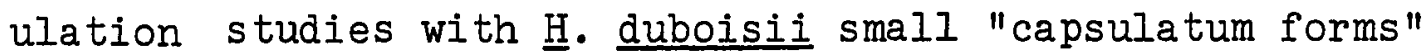
of the yeast cells may be produced in the early stages, while in the later stages, after 2 months, large forms 
"auboisii forms" predominate (2). Okudaira and Schwarz concluded it was possible to differentiate $\underline{H}$. duboisii from H. capuslatum by its size in the parasitic phase, its different pathogenicity, and particular tissue response in hamster and mice (3). Pine et al. reported morphological differences and concluded that the ability to form the "duboisii form" varied with isolate, the experimental animal host and with the form of the yeast phase used as the inocolum. (33). Coudert and Coly reported differences in the collodion agglutination test of both organisms $(9,36)$. Several biochemical tests for the differentiation of $\underline{H}$. duboisii from $\underline{\mathrm{H}}$. capsulatum, have been reported. Coremeous reported differences in the production of urease in Bactourea broth and Difco urea agar at $25^{\circ} \mathrm{c}(8)$. Pine and Drouchet, also reported differences in the induction and conservation of the yeast phase in chemically defined medium (33), and recently Berliner reported differences in gelatin hydrolysis of both organisms (4).

The filtrate derived from prolonged growth in liquid synthetic medium of the mycelial phase of $\underline{H}$. capsulatum has been designated Histoplasmin (54). Histoplasmin contains an active polysacchride fraction and a protein fraction (38) which precipitate in the presence of specific serum antibody and elicit a skin reaction when injected intradermally into sensitive animals. (49). This material has been used extensively as the antigen in complement fixation, 
4

precipitin, collodion agglutination, capillary tube agglutination, and skin tests for histoplasmosis $(10,18,23)$. Histoplasmin production has been reported to occur as early as two weeks after inoculation. In addition, various media have been shown to elicit Histoplasmin formation (24).

Heiner, (19) using the Ouchterlony technic, detected six different antigens in the crude mycelial filtrates. However, only one antigen isolated by continuous flow electrophoresis, designated as "h", was specific for active histoplasmosis (19).

In 1960, Green et al., reported partial purification of histoplasmin by the removal of some $75 \%-80 \%$ inert material by means of column chromotography in DEAE-cellulose (18). Sprouse, 1967, reported the chromotographic separation and chemical characterization of histoplasmin. These investigations have resulted in isolation of a component active in cutanous reaction which has been characterized chemically with respect to composition (47). A long term controlled study of histoplasmin was recently reported by Goodman, Sprouse, and Larsh. This study showed a variation in time required for skin test antigen production. There appeared to be no specific time for harvesting cultures of H. capsulatum to produce an histoplasmin that will give a standard skin test on homologously infected guinea pigs. Concurrent chemical studies on the culture filtrate indicated that skin test activity may be related to chemical 
changes in the medium. There was an indication also of a close relationship between increasing skin test potency, with increasing protein and decreasing total carbohydrates and reducing sugars. (17).

Recent investigations have demonstrated the occurrence of $5 \underline{H}$. capsulatum serotypes (20). Specific flourescent antibodies developed to date have stained only 4 of the 5 serotypes. Antibodies produced against the most antigenically complex $\underline{\mathrm{H}}$. capsulatum serotype were labelled with flourescein isothiocyanate to develop a reagent specific for $\underline{H}$. capsulatum and reactive with all the known serotypes. The unabsorbed reagent, in addition to staining all the $\underline{H}$. capsulatum serotypes, stained culture by Blastomyces dermatitidis, $\mathrm{H}$. duboisii and several Candida species and a variety of other fungi. The conclusion was that differentiation of $\underline{H}$. capsulatum from $\underline{H}$. duboisii may be accomplished only by animal inoculation or biochemical tests ( 5$)$.

All biological systems have the inherent aspect of variations within a popullation. Variation in natural resistance to Histoplasmosis has been studied. Loosli observed that age and sex were definite factors in this respect (24). Also Saslaw and Schaefer observed that young and old males were the most susceptible to $\underline{H}$. capsulatum infection (37). Therefore, the nature of the infection of $\underline{H}$. 
duboisii on male guinea pigs followed histopathologically also was included in this study.

In view of the importance of histoplasmin as a tool to determine the epidemiologic pattern of the disease, this study was designed to elicit information pertinent to the biochemical nature of the crude filtrate of $\underline{H}$. duboisii, and its efficacy as a skin test antigen. 


\section{MATERIALS AND METHODS}

The isolates of $\underline{H}$. duboisii used in this study are shown in Table 1. The filtrate derived from the mycelial phase of $\underline{H}$. duboisii 2100 , and $\underline{H}$. duboisii 5049, dialysed and lypholized were supplied, originally, by Dr. Drouchet, Pasteur Institute, Paris, France. All organisms used were converted to yeast phase on blood agar.

\section{Infection Study}

Experimental Infection of Animals.--A total of 24, Hartley strain, male guinea pigs were used for the study. Twelve guinea pigs received intraperitoneal injection of yeast cells and the remaining received intraperitoneal injection of mycelial fragments homogenized in a teflon grinder. Each injection was $3 \times 10^{6}-4 \times 10^{6}$ viable myceliai fragments or $2 \times 10^{8}$ viable yeast cells contained in $1 \mathrm{mI}$ as determined by viability plate and hemacytometer count. (Table 2.)

The guinea pigs were sacrificed late in infection when the animals were near death. Autopsies were performed on them. Histopathological sections of the spleen, liver, 
TABLE 1.--List of isolates of $\underline{H}$. duboisii used in the study

\section{Organism}

H. duboisii $R v 19138$

H. duboisii 142

H. duboisii 369

H. $\frac{\text { duboisji }}{(B 684)} 2100$

H. duboisii 5049

H. $\frac{\text { duboisii }}{(B 939)} 210$

H. duboisii 9096
Source

Isolated in the Congo, and supplied by $\mathrm{Dr}$. R. Vanbreuseghem.

Isolated in Okayama, Japan in 1956 and supplied by Dr. R. S. Pore

Isolated in Italy, supplied by Dr. Pore

Isolated from pulmunary histoplasmosis in Conakry, Guinea in 1962 by Dr. E. Drouhet, and supplied by $\mathrm{Dr}$. L. Ajello

Isolated from an abcess in Yaounde, Cameroon in 1961 and supplied by Dr. E. Drouhet.

Isolated from human histoplasmosis in Ibadan, Nigeria, supplied by Dr. Betty Clark and Dr. L. A jello.

Isolated from human histoplasmosis in Ibadan, Nigeria, supplied by Dr. Betty Clark. 
TABLE 2.--Experimental Infection of Guinea Pigs

\begin{tabular}{|c|c|c|c|}
\hline Organism & $\begin{array}{c}\text { Inoculation } \\
\text { Rt. }\end{array}$ & $\begin{array}{l}\text { Inoculation } \\
\text { Sch. - Days }\end{array}$ & $\begin{array}{c}\text { Inoculum } \\
\text { Size }\end{array}$ \\
\hline H. $\frac{\text { duboisii }}{\text { Mycelium }} 142$ & $I-P$ & 1 & $6 \times 10^{5}$ \\
\hline ㅍ. $\frac{\text { duboisii }}{\text { Yeast Cells }} 142$ & I-P & 1 & $4 \times 10^{7}$ \\
\hline ㅍ. $\frac{\text { duboisii }}{\text { Mycelium }} 9096$ & $\begin{array}{l}I-P \\
I-P\end{array}$ & $\begin{array}{l}1 \\
1\end{array}$ & $\begin{array}{l}5.5 \times 10^{5} \\
3.2 \times 10^{7}\end{array}$ \\
\hline $\begin{array}{l}\text { H. } \\
\frac{\text { duboisii }}{\text { Mycelium }} 369 \\
\text { Yeast Cells }\end{array}$ & $\begin{array}{l}I-P \\
I-P\end{array}$ & $\begin{array}{l}1 \\
1\end{array}$ & $\begin{array}{l}4.2 \times 10^{5} \\
3.5 \times 10^{7}\end{array}$ \\
\hline ㅍ. $\frac{\text { duboisii }}{\text { Mycelium }} 142$ & $\begin{array}{l}I-P \\
I-P\end{array}$ & $\begin{array}{l}5 \\
5\end{array}$ & $\begin{array}{l}9 \times 10^{5} \\
6 \times 10^{7}\end{array}$ \\
\hline H. $\frac{\text { duboisii }}{\text { Mycelium }} 9096$ & $\begin{array}{l}I-P \\
I-P\end{array}$ & $\begin{array}{l}5 \\
5\end{array}$ & $\begin{array}{l}8 \times 10^{5} \\
9 \times 10^{6}\end{array}$ \\
\hline $\begin{array}{l}\text { H. } \\
\frac{\text { duboisii }}{\text { Mycelium }} 369 \\
\text { Yeast Cells }\end{array}$ & $\begin{array}{l}I-P \\
I-P\end{array}$ & $\begin{array}{l}5 \\
5\end{array}$ & $\begin{array}{l}8 \times 10^{4} \\
7 \times 10^{6}\end{array}$ \\
\hline
\end{tabular}


lung, heart, nodules and testis were made and stained with methaneamine silver and hematoxylin and eosin.

\section{Antigen Study}

Ion-Exchange Chromotography.--The filtrate derived from the mycelial phase of $\underline{H}$. duboisii grown for $2-3$ months in liquid synthetic medium at $27^{\circ}$, were concentrated and dialyzed against distilled water. The cultures included two human isolates from the University of Ibadan, Nigeria, and seven isolates obtained from Dr. Vanbreuseghem, Institute of Tropical Medicine, Antwerp, Belgium. The antigens were precipitated by half saturation of the solution with $\left(\mathrm{NH}_{4}\right)_{2} \mathrm{SO}_{4}$, the amount of protein was determined by Lowry method (27).

DEAE-Sephadex $(A-25)$ was prepared and packed into a $1.2 \times 45 \mathrm{~cm}$ glass column containing $3 \mathrm{gm}$ of absorbent, and equilibrated with $\mathrm{pH} 8.0$ phosphate buffer. The sample of partially purified crude filtrate was dialyzed for 24 hours, against the same buffer in a revolving dalyzer. Three $\mathrm{ml}$ of the solution containing approximately $200 \mathrm{ug}$ of protein were introduced into the column. Gradient elution with increasing molarity and decreasing $\mathrm{pH}$ from 8.0 to 3.5 was accomplished by introducing $\mathrm{NaH}_{2} \mathrm{PO}_{4}$ through a constant volume mixing chamber containing the starting buffer. The effluent was collected in $2 \mathrm{ml}$ fractions at a flow rate of approximately $20 \mathrm{ml} / \mathrm{hr}$. Optical densities of the fractions at 
$280 \mathrm{mu}$ and $260 \mathrm{mu}$ were determined in a Beckman DU spectrophotometer. Fractionation was carried out at $25^{\circ} \mathrm{c}$.

Volumes of the-effluent were pooled, concentrated using dialysis tubing, and pervaporation; and then dialyzed against $0.85 \% \mathrm{NaCl}$, and were examined for antigenic activity by double diffusion in agar (31) and immuno-electrophoresis (1), using sera from guinea pigs hyperimmunized and infected with $\underline{H}$. duboisi $\underline{i}$ and $\underline{H}$. capsulatum.

\section{Antigen Potency as Affected by Culture Age}

Preparation of Antigen.--Antigens were prepared from two isolates of Histoplasma duboisii. Mycelium for inoculum was scraped from 18-day old sabouraud's dextrose agar slants into sterile physiological saline. The suspension was homogenized in a teflon grinder and the number of viable particles determined by culturing respective serial dilutions on ten sabouraud's dextrose agar plates. The fragments of the two organisms were grown in asparagine medium (Smith, 1943) Table 3, 24 liters of the medium were prepared in a 50-liter carboy containing a large magnetic stirring bar, and was autoclaved for 30 minutes at $15 \mathrm{psi}$ and $121^{\circ} \mathrm{c}$. Prior to inoculation, one liter was withdrawn for use as a sterile negative control skin test antigen.

Each carboy of medium was inoculated with $0.7 \times 10^{4}$ and $0.6 \times 10^{4}$ total mycelial fragments $/ \mathrm{ml}$ of medium as 
TABLE 3.--Smith's Asparagine Synthetic Medium

$\begin{array}{lc}\text { 1-Asparagine } & 7.0 \mathrm{~g} \\ \text { Ammonium chloride } & 7.0 \mathrm{~g} \\ \text { Dipotassium phosphate C.P. }\left(\mathrm{K}_{2} \mathrm{HPO}_{4} \cdot 5 \mathrm{H}_{2} \mathrm{O}\right) & 1.31 \mathrm{~g} \\ \text { Sodium citrate C.P. }\left(\mathrm{Na}_{3} \mathrm{C}_{6} \mathrm{H}_{5} \mathrm{O}_{7} \cdot 5 \quad 1 / 2 \mathrm{H}_{2} \mathrm{O}\right) & 0.9 \mathrm{~g} \\ \text { Magnesium sulphate U.S.P. }\left(\mathrm{MgSO}_{4} \cdot 7 \mathrm{H}_{2} \mathrm{O}\right) & 1.5 \mathrm{~g} \\ \text { Ferric citrate U.S.P.VIII }(\mathrm{Scales}) & 0.3 \mathrm{~g} \\ \text { Dextrose grade cerolose U.S.P.X. } & 10.3 \mathrm{~g} \\ \text { Glycerine C.P.(U.S.P.) } & 25.0 \mathrm{~g} \\ \text { Distilled water to make } & 1000.0 \mathrm{ml} \\ & \text { pH } 6.2\end{array}$


determined by hemacytometer count, and $2.4 \times 10^{2}$ and $1.8 \times 10^{2}$ viable fragments/ml of medium as determined by plate counts of $\underline{H}$. duboisii 2100 and $\underline{H}$. duboisii respectively (Table 4). The suspension was thoroughly mixed using a magnetic stirrer, and as stirring continued 1 liter aliquots were asceptically dispensed into 2 liter flasks. The cultures were incubated statically at $30^{\circ} \mathrm{c}$ in an environmental controlled chamber with relative humidity of about $75 \%$ to minimize evaporation during long term incubation. At weekly intervals for four weeks, two week intervals for four weeks, and then at monthly intervals, 1 flask of culture was randomly selected for antigen preparation. A portion of the medium was plated onto nutrient agar to check for contamination. The mycelium was killed by treatment with merthiolate at final concentration of $1: 10,000$ for 48 hours. The matted colonies (Fig. 1) were removed from the flask by filtering through cheese cloth into a Seitz filter. The resultant filtrate was placed at $5^{\circ} \mathrm{c}$ overnight and refiltered through Seitz filter the following day. The second filtrate was dispensed into $100 \mathrm{ml}$ aliquots, sealed in new sterile antigen bottles and stored at $5^{\circ} \mathrm{c}$ for further use.

Sensitization of Animals.--Animals used for these studies were female and male Hartley guinea pigs, initial weights of 400-1,000 gm. Each animal was given a number and randomized by weight into cages with four animals per cage. 
TABLE 4.--Preparation of Crude Mycelial Growth Filtrates

\begin{tabular}{|c|c|c|c|c|c|}
\hline \multirow[b]{2}{*}{ H. duboisii } & \multirow[b]{2}{*}{$\begin{array}{l}\text { Culture } \\
\text { Age } \\
\text { (days) }\end{array}$} & \multirow[b]{2}{*}{ Crude filtrate } & \multicolumn{2}{|c|}{ Inoculum Size } & \multirow[b]{2}{*}{ \% Viability } \\
\hline & & & $\begin{array}{c}\text { Total } \\
\text { Particles } \\
\text { /ml of } \\
\text { medium }\end{array}$ & $\begin{array}{l}\text { Viable } \\
\text { Particles } \\
\text { /ml of } \\
\text { medium }\end{array}$ & \\
\hline H. $\frac{\text { duboisii }}{2100}$ & 18 & H. d 2100 & $0.7 \times 10^{4}$ & $2.4 \times 10^{2}$ & $3.4 \%$ \\
\hline H. $\frac{\text { duboisii }}{210}$ & 18 & H. d 2100 & $0.6 \times 10^{4}$ & $1.8 \times 10^{2}$ & $3 \%$ \\
\hline$* \mathrm{H}-42$ & & $\mathrm{H}-42$ & - & - & - \\
\hline
\end{tabular}




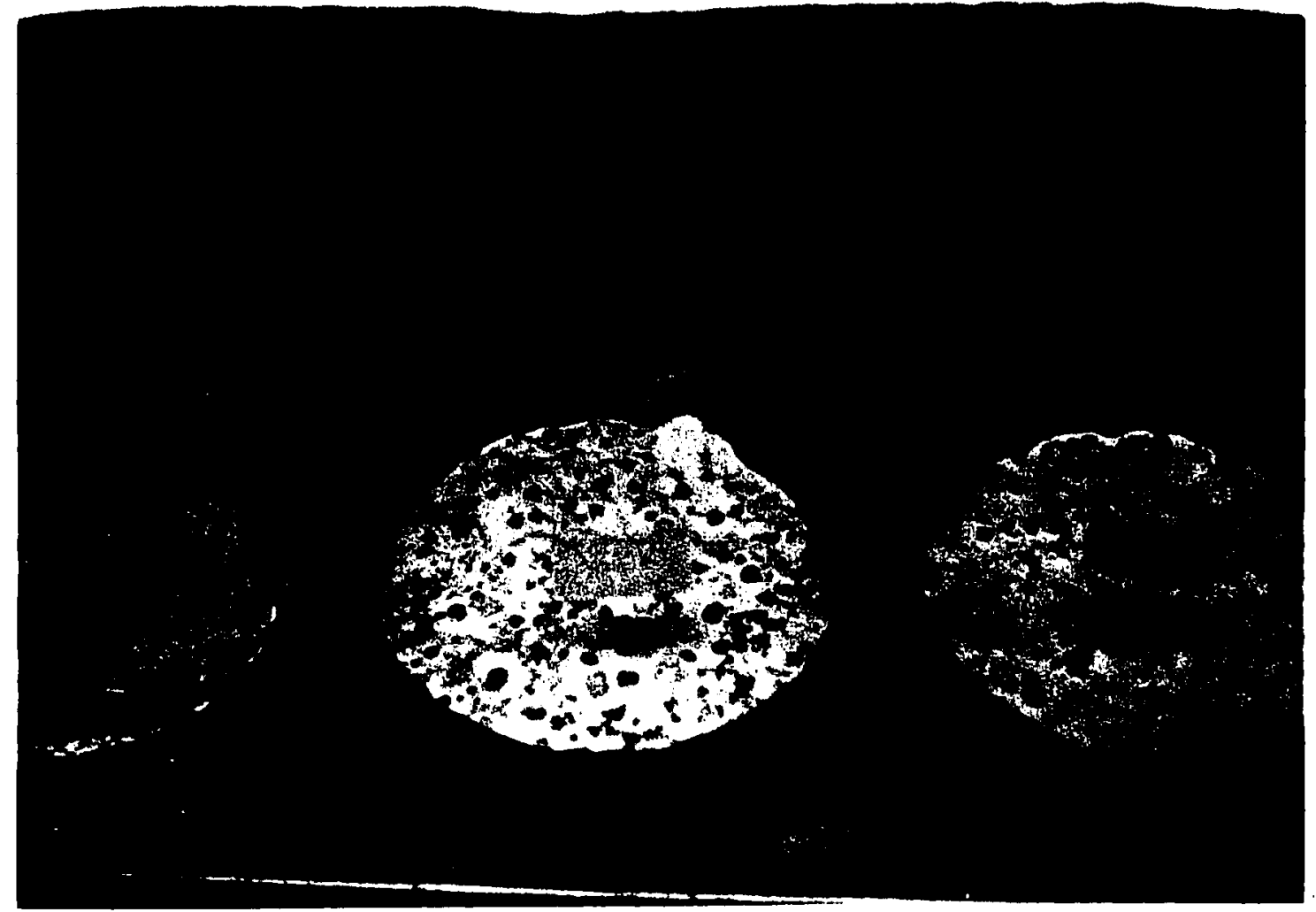

Fig. 1.--H. duboisii culture in asparagine medium showing white matted colonies. 
Twenty-five animals were used for testing $\underline{H}$. duboisii 2100 isolate, 25 animals for $\underline{H}$. duboisii 210 isolate, 25 animals were hyperimmunized with formalin killed mycelium fragments of $\underline{H}$. duboisii 210 and 25 were used as controls. All animals were sensitized by intraperitoneal inoculation of suspensions containing viable mycelial particles of the two isolates, except 25 animals which were given killed mycelial particles in $0.5 \%$ concentrated formalin. Inoculation schedules, skin test schedule and dosages are given on Table 5.

Skin Testing Procedure.--The antigens were assayed for relative skin test potency by intradermal injection of $0.1 \mathrm{ml}$ of each antigen into a predetermined number of randomized sites on the test and control animals. Six sites were prepared on each animal by shaving the area to be tested. The antigens were randomly assigned to each site on all homologously and heterologously sensitized animals; and also tested on animals sensitized with $\underline{H}$. capsulatum. Each antigen was tested on a minimum of 5 sites. The $1: 25$ dilution of $\mathrm{H}-42$ histoplasmin and saline control were included in the antigens tested. Undiluted, $1: 2,1: 10$ dilutions of H. duboisii 2100 and $\underline{H}$. duboisii 210 antigens were used as test antigens. Erythema and induration were measured perpendicular to the line of inoculation, and all readings were made by the same reader with all sites coded to assure 
TABLE 5.--Sensitization and Skin Testing Schedule

\begin{tabular}{|c|c|c|c|c|c|}
\hline \multirow[b]{2}{*}{ Organisms \& Antigens } & \multirow[b]{2}{*}{$\begin{array}{l}\text { Inoculation } \\
\text { Route }\end{array}$} & \multirow{2}{*}{$\begin{array}{c}\text { Inoculation } \\
\text { Schedule } \\
\text { (Days) }\end{array}$} & \multicolumn{2}{|c|}{ Inoculum Size } & \multirow[b]{2}{*}{ Volume } \\
\hline & & & $\begin{array}{l}\text { Total } \\
\text { Count }\end{array}$ & $\begin{array}{l}\text { Viable } \\
\text { Count }\end{array}$ & \\
\hline H. d. 2100 & $I-P$ & 1 & & $1.04 \times 10^{3}$ & \\
\hline H. d. 2100 & $\mathrm{I}-\mathrm{P}$ & 28 & & $1.04 \times 10^{3}$ & \\
\hline $\begin{array}{l}\text { H.d } 2100-1,2,3,4, \text { wks old } \\
\text { Antigen }(1: 0,1: 2,1: 5,1: 10)\end{array}$ & $I-D$ & 60 & & & $0.1 \mathrm{ml}$ \\
\hline H.d 210 & $\mathrm{I}-\mathrm{P}$ & 1 & & $1.05 \times 10^{3}$ & \\
\hline H.d 210 & $\mathrm{I}-\mathrm{P}$ & 28 & & $1.05 \times 10^{3}$ & \\
\hline $\begin{array}{l}\text { H.d } 210-1,2,3,4, \text { wks old } \\
\text { Antigen }(1: 0,1: 2,1: 5,1: 10)\end{array}$ & $I-D$ & 60 & & & $0.1 \mathrm{ml}$ \\
\hline H.d 210-Formalin killed & $\mathrm{I}-\mathrm{P}$ & 1 & $2.5 \times 10^{5}$ & & \\
\hline H.d 210 & $\mathrm{I}-\mathrm{P}$ & 2 & $5 \times 10^{5}$ & & \\
\hline H.d 210 & $\mathrm{I}-\mathrm{P}$ & 3 & $1.25 \times 10^{6}$ & & \\
\hline H.d 210 & $\mathrm{I}-\mathrm{P}$ & 28 & $2.5 \times 10^{5}$ & & \\
\hline H.d 210 & $I-P$ & 29 & $5 \times 10^{5}$ & & \\
\hline H.d 210 & $I-P$ & 30 & $1.25 \times 10^{6}$ & & \\
\hline H.d 210 & $I-P$ & 40 & $5 \times 10^{5}$ & & \\
\hline
\end{tabular}


TABLE 5.--Continued

\begin{tabular}{|c|c|c|c|c|c|}
\hline \multirow[b]{2}{*}{ Organisms \& Antigens } & \multirow[b]{2}{*}{$\begin{array}{l}\text { Inoculation } \\
\text { Route }\end{array}$} & \multirow{2}{*}{$\begin{array}{l}\text { Inoculation } \\
\text { Schedule } \\
\text { (Days) }\end{array}$} & \multicolumn{2}{|c|}{ Inoculum Size } & \multirow[b]{2}{*}{ Volume } \\
\hline & & & $\begin{array}{l}\text { Total } \\
\text { Count }\end{array}$ & $\begin{array}{l}\text { Viable } \\
\text { Count }\end{array}$ & \\
\hline $\begin{array}{l}\text { H.d } 210 \text { \& H.d } 2100-1,2,3 \text {, } \\
\text { 4, wks old. Antigen (Dil. } \\
1: 0,1: 2,1: 5,1: 10)\end{array}$ & $I-D$ & 60 & & & $0.1 \mathrm{ml}$ \\
\hline H.d 2100 & $I-P$ & 80 & & $1.04 \times 10^{3}$ & \\
\hline $\begin{array}{l}\text { H.d } 2100-6,8,12 \text { wks old } \\
\text { Antigen (Dil } 1: 0,1: 2,1: 5,1: 10 \text { ) }\end{array}$ & $I-D$ & 94 & & & $0.1 \mathrm{ml}$ \\
\hline$H-42(1: 25)$ & $I-D$ & 94 & & & $0.1 \mathrm{ml}$ \\
\hline H.d 210 - Formalin killed & $I-P$ & 80 & $5 \times 10^{5}$ & & \\
\hline $\begin{array}{l}\text { H.d } 210 \text { \& H.d } 2100 \\
6,8,12 \text {, wks old } \\
\text { Antigen (Dil. } 1: 0,1: 2,1: 5, \\
1: 10 \text { ) }\end{array}$ & $I-D$ & 94 & & & $0.1 \mathrm{mI}$ \\
\hline $\mathrm{H}-42$ (Dil. $1: 25)$ & $I-D$ & 94 & & & $0.1 \mathrm{ml}$ \\
\hline $\begin{array}{l}\text { H.d } 210 \& \mathrm{H} . \mathrm{d} 2100 \\
1,2,3,4,5,6 \text {, months old }\end{array}$ & $I-D$ & 180 & & & $0.1 \mathrm{ml}$ \\
\hline $\mathrm{H}-42$ (Dil. $1: 25)$ & $I-D$ & 180 & & & $0.1 \mathrm{ml}$ \\
\hline $\begin{array}{l}\text { H.d } 210(1,2,3,4,5,6, \\
\text { months old }\end{array}$ & $I-D$ & 180 & & & $0.1 \mathrm{ml}$ \\
\hline
\end{tabular}


TABLE 5.--Continued

\begin{tabular}{|c|c|c|c|c|c|}
\hline & & & Inoculum & Size & \\
\hline Organisms \& Antigens & $\begin{array}{l}\text { Inoculation } \\
\text { Route }\end{array}$ & $\begin{array}{l}\text { Schedule } \\
\text { (Days) }\end{array}$ & $\begin{array}{l}\text { Total } \\
\text { Count }\end{array}$ & $\begin{array}{l}\text { Viable } \\
\text { Count }\end{array}$ & Volume \\
\hline $\mathrm{H}-42$ & $I-D$ & 180 & & & $0.1 \mathrm{mI}$ \\
\hline $\begin{array}{l}\text { H.d } 2100(1,2,3,4,5,6, \\
\text { months old })\end{array}$ & $I-D$ & 180 & & & $0.1 \mathrm{ml}$ \\
\hline $\mathrm{H}-42$ & $I-D$ & 180 & & & $0.1 \mathrm{ml}$ \\
\hline
\end{tabular}


unbiased reading. Only 48 hour readings were used for statistical evaluation.

\section{Serżological Study}

Collection of Sera.--Random samples from the four animal groups were bled using the cardiac puncture technique. These initial bleedings served as the control in subsequent serological tests. All bleedings were performed using five $\mathrm{ml}$ syringes and 1 inch 20 gauge needles. At $0,46,106$, and 166 days post injection, random sample animals were bled. Five animals from each group were bled at the same periods. Sera were decanted from tubes and stored at $4^{\circ}$ until used. All Sera were coded by number so that the specimen was examined for titer and characterized electrophoretically without knowledge of the source of the specimen. The Sera collected in the study were titrated for C.F. antibody concentrations. The complement fixation technique described by Lackman (22) was used for titering of $\underline{H}$. duboisii infected animals.

\section{Biochemical Determinations}

Protein determinations were made by the Lowry method using bovine serum albumin as a standard (Lowry, Rosebrough, Farr, and Randall, 1957) (27). These determinations were made on crude and lypholized antigens which had been dialized against distilled water. 
Total carbohydrate was determined by Anthrone reagent (42) and reducing sugars were determined by the method of Somogyi, 1945 (46).

Electrophoresis of Antigen in Acrylamide Gels.-Stock solutions for anionic gel systems having a running pH 9.3 were used in this study. (Table 6).

Original stock solutions were usable for 6 months, with the exception of those containing ammonium persulfate, which must be prepared at weekly intervals. Preparation of acrylamide gels was accomplished in the following manner:

1. The sample gel solution and chemicals were prepared and all preparations were stored in tinfoil covered bottles and maintained under refrigerations.

2. Preparation of gel tubes.

a. All tubing had an inner diameter of 5 millimeters and $7.5 \mathrm{~cm}$ in length. Tubes were cleaned with $7 \mathrm{X}$ cleaning solution, rinsed through distilled water, and finally rinsed with a 1:200 solution of Kodak Photo-Flo 200 solution and allowed to dry at room temperature.

b. Tubes were next fitted with the hollow rubber cap (Canalco \#3-1768) to seal one end and placed in GEL Polymerization Rack (Canalco \#3-1762). Adjustment of tube includes leaving all the bottom ends as well as leveling the entire apparatus.

c. Using a $1 \mathrm{ml}$ syringe fitted with a 20 gauge needle and 5 inches length of plastic tubing, each tube was 
TABLE 6.--Siock Solution for ANIONIC GEL SYSTEM Running pH-9.3

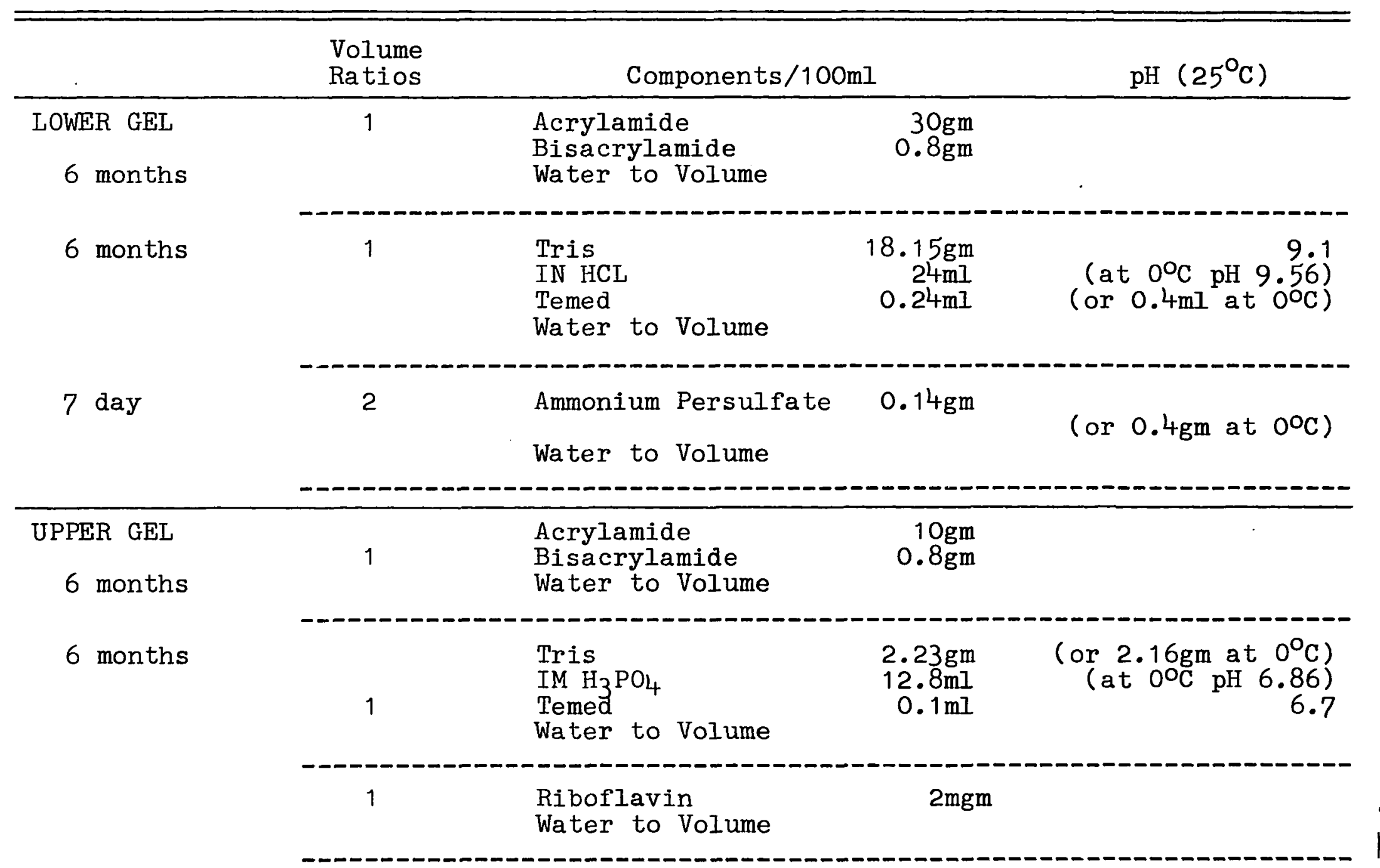


TABLE 6.--Continued

\begin{tabular}{|c|c|c|c|c|}
\hline & $\begin{array}{l}\text { Volume } \\
\text { Ratios }\end{array}$ & Components/10 & & $\mathrm{pH}\left(25^{\circ} \mathrm{C}\right)$ \\
\hline $\begin{array}{l}\text { UPPER GEL } \\
7 \text { day }\end{array}$ & 1 & $\begin{array}{l}\text { Ammonium Persulfate } \\
\text { Water to Volume }\end{array}$ & $80 \mathrm{mgm}$ & \\
\hline \multicolumn{5}{|c|}{ Components/Liter } \\
\hline UPPER BUFFER & & $\begin{array}{l}\text { Tris } \\
\text { Glycine } \\
\text { Water to Volume }\end{array}$ & $\begin{array}{l}5.16 \mathrm{gm} \\
3.48 \mathrm{gm}\end{array}$ & (at $0^{\circ} \mathrm{C} \mathrm{pH} \mathrm{9.64)}$ \\
\hline LOWER BUFFER & & $\begin{array}{l}\text { Tris } \\
\text { IN HCL } \\
\text { Water to Volume }\end{array}$ & $\begin{array}{r}14.5 \mathrm{gm} \\
60 \mathrm{ml}\end{array}$ & $\left(\right.$ at $0^{\circ} \mathrm{C}$ pH 8.84 ) \\
\hline
\end{tabular}


24

filled with $0.75 \mathrm{ml}$ of the lower gel solution. The surface of the gel solution was next layered with approximately $0.1 \mathrm{ml}$ of distilled water to insure the formation of a flat upper surface. The lower-gel solution was allowed to polymerize for 30 minutes. Next the layering water was decanted along with any unpolymerized gel solution. This was most easily accomplished using rolled absorbing tissue paper.

d. The layering technique was repeated using $0.2 \mathrm{ml}$ of the upper gel solution. Again the upper gel solution was overlayed with $0.1 \mathrm{ml}$ distilled water. A fluorescent light assembly (Canalco \#3-1764) was placed approximately three inches behind the apparatus. The upper gel solution was photopolymerized 20 minutes. Again the layering water and any unpolymerized gel solution was decanted.

e. Rubber caps were removed from the lower ends of the tubes and the tubes were placed in the tube holder assembly of the upper electrophoresis chamber, positioning the upper gel in the upper position. Upper buffer solution was added to the upper buffer chamber, sufficient to cover the upper electrode of the plastic cover when it was in place. A hanging drop of upper buffer was added to the lower end of the tube to prohibit air bubble formation. The lower buffer chamber was partially filled with lower buffer solution to a level approximately $1 \mathrm{~cm}$ above the lower end of gel tube. 
f. 50 microliters of sample antigen were carefully layered on top of the upper gel. The front was marked by adding $1 \mathrm{ml}$ of a Bromophenol blue dye (.001\%) to the upper buffer compartment.

g. Adjustment of a uniform current, 3.3 ma per column, to pass through gel tubes was made. The leading migrating front marked by the dye was followed visually. The run was terminated when this front reached a distance of about 1-2 $\mathrm{mm}$ from the bottom of the gel column. The time for the run was approximately 50 minutes.

$$
\text { h. At completion of electrophoresis, the gel }
$$
columns were removed from the glass tubes by rimming with a 22 gauge needle, while forcing water through the needle to aid in gel removal. Upon removal, gels were immediately fixed and stained for 60 minutes in a solution of $0.5 \%$ Amide Schwartz dye in $7 \%$ acetic acid. Duplicate samples were stained with Schiff's reagent and Sudan black B for determination of carbohydrate and lipid content respectively. (32)

i. Destaining the gel column was done in the assembly holder. Each tube was positioned in the tube holder assembly, both chambers were filled with $7 \%$ acetic acid and adjustment for a current of 5 ma per gel column from the power supply was made. All background stain could be removed in approximately 2-3 hours. Gel columns were stored in vials containing $7 \%$ acetic acid. 
Evaluation of the Differences between Patterns.-Three visual criteria were used in the preliminary assessment of the acrylamide gels: (a) number of bands in the gels; (b) the position of the bands; (c) the density and width of the bands as an estimate of the relative amount of protein in each fraction. Quantitation of the gel columns is based on densitometer tracings.

Gel columns were read and recordings of the tracings were performed using a Canalco Model 5 Microdensitometer and a Servoriter II Recorder respectively.

The disc-electrophoretic method achieves its separations by electrophoresis of material in a polyacrylamide gel matrix of defined pore size and shape. The $7 \%$ gel used here produced an average pore approximately $50 \AA$ in diameter. Separations are sharpened by the use of thin starting zones where a discontinuous buffer system is combined with a large (2 1/2) gel for an initial period of electrophoresis. The buffers and $\mathrm{pH}$ are selected to conform to conditions permitting the application of the Kohlrausch regulating function $(6,32)$. The initial period of electrophoresis occurs in the large pore gel which is referred to as the stacking gel. The function of this gel is to serve as a preconcentrating step. The proteins in the sample upon entry into the separating gel are stacked in bands, one above the other, in order of decreasing mobility. 


\section{RESULTS}

\section{Infection Study}

Twenty-one of the 24 guinea pigs died and autopsies were performed. Some of the guinea pigs were sacrificed when it was believed they were going to die. All 21 guinea pigs developed severe orchitis. The guinea pigs infected with the yeast cells showed this symptom as early as 2-4 months, while those infected with the mycelial fragments showed the symptom between the 5 th and 6 th months of infection. One guinea pig infected with the yeast cells did not die. Two guinea pigs infected with mycelium fragments did not die and they did not develop orchitis. At autopsy all 21 guinea pigs had very large testis and in most cases with large ulcers. The liver and spleen were enlarged. In some cases fibrinous exudate cover the entire lower peritonuem. There was no evidence of total necrosis of any organ except some grayish-pink color in spots on the liver and spleen.

The development in male guinea pigs was macro-. sopically and microscopically as follows: First only the peritonuem and testis (Fig. 2) were involved, with the 

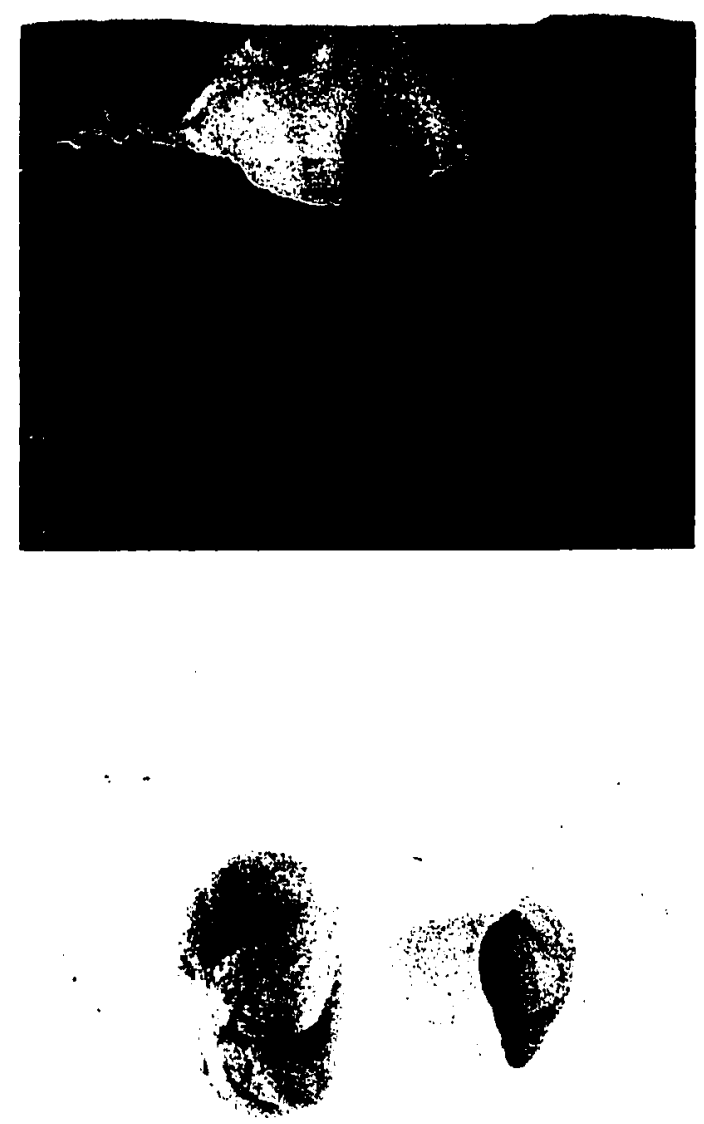

$\wedge$

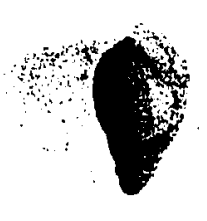

in

Fig. 2.--H. duboisii infected guinea pig with orchitis. A. Infected. B. Normal. 
gradual disappearance of the spermatogonic and sertoli cells; and finally, the tubercles were completely filled with large ovoid, budding yeast cells. (Fig. 3A). Later in the course of infection, spleen, liver, and lung contain a few isolated yeast cells (Fig. 3, B,C, \& D). Towards the end a truly dessminated disease was evident with the development of nodules (Fig. 3F) along the abdomen, isolated nodules on the nose area (Fig. 3E) and large ulcers on the testis. (Fig. 2).

\section{Antigen Study}

Separation of Specific Antigens by Ion-Exchange Chromotography.--In the immuno-diffusion tests, one band of common identity was formed by $\underline{\mathrm{H}}$. duboisii and $\underline{\mathrm{H}}$. capsulatum crude antigens with serum from $\underline{H}$. duboisi $\underline{i}$ and $\underline{H}$. capsulatum infected animals. Two and occasionally three additional bands were demonstrated with $\underline{H}$. capsulatum (Fig. 4A). Also

one band of common identity was formed by $\underline{H}$. duboisii and $\underline{H}$. capsulatum crude antigens with serum from $\underline{H}$. duboisii infected animals. An additional band is demonstrated with $\underline{H}$. duboisii. (Fig. 4B). In the immuno-electrophorestic test of $\underline{H}$. duboisii and $\underline{H}$. capsulatum crude filtrates with sera of $\underline{H}$. duboisii infected animals, two bands were formed with H. duboisii while only one was formed with $\underline{H}$. capsulatum. (Fig. 4C).

Fig. 5 shows the result of the fractionation of the antigen. Only pool 8 and pool 9 exhibit antigenic activity 

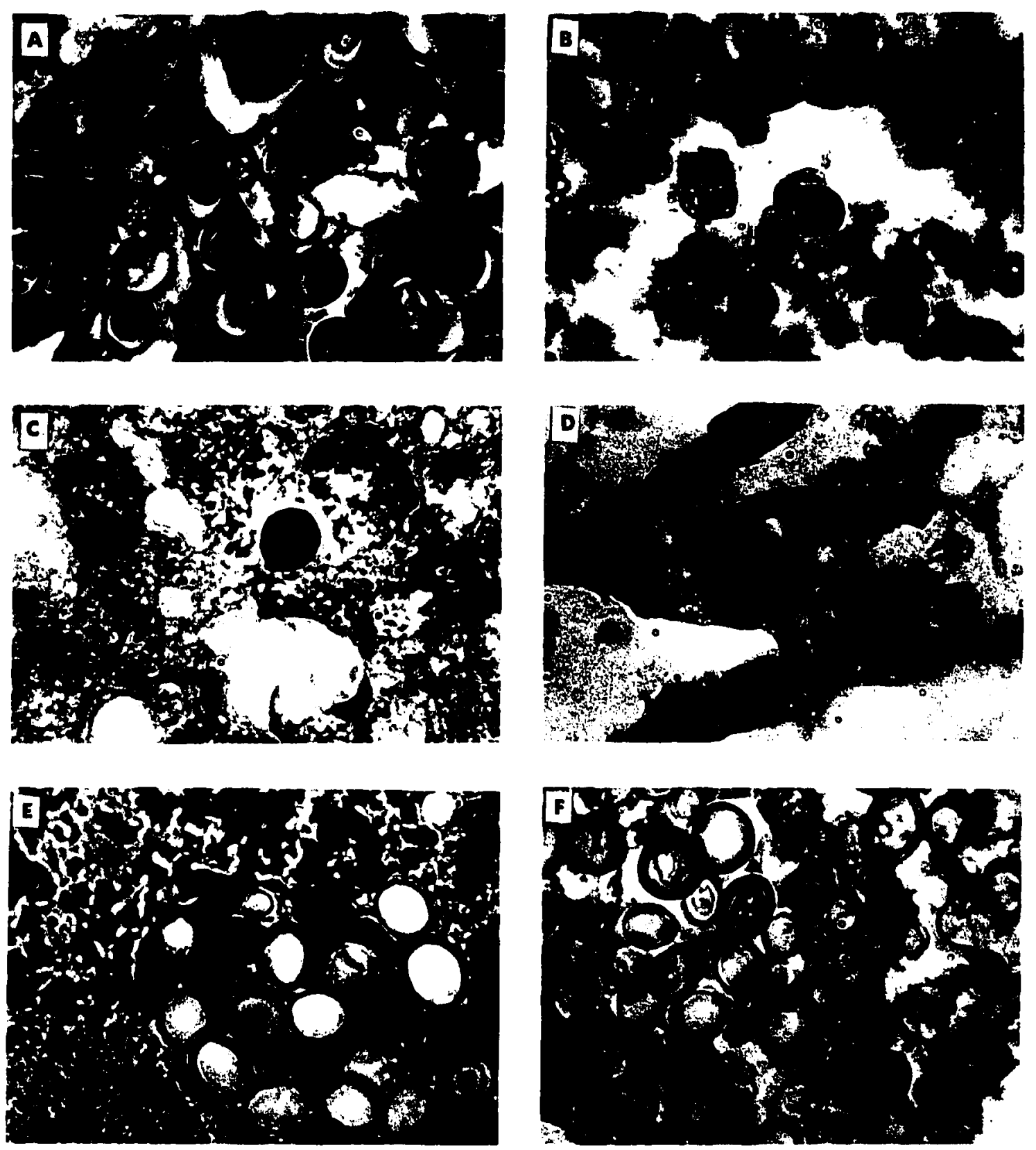

Fig. 3.--Histopathological sections of tissues of guinea pigs infected with $H$. duboisii yeast cells and mycelial fragments: A. Testis, B. Spleen, C. Liver, D. Lung, E. Nose nodule, F. Lymph node. 
31
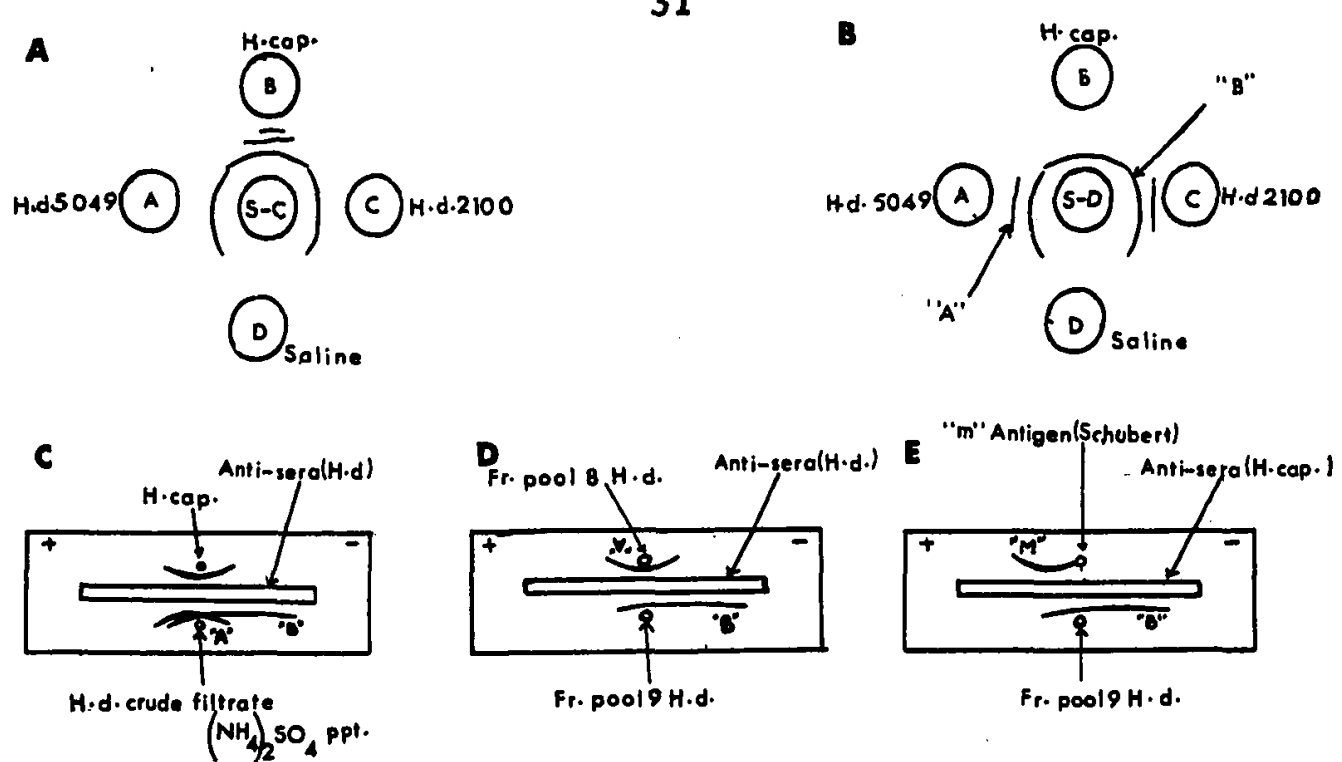

Fig. 4.--Immuno-diffusion and immuno-electrophoretic patterns of mycelial filtrates of $\underline{H}$. duboisii and H. capsulatum with serum of guinea pigs infected with H. duboisii and $\underline{H}$. capsulatum.

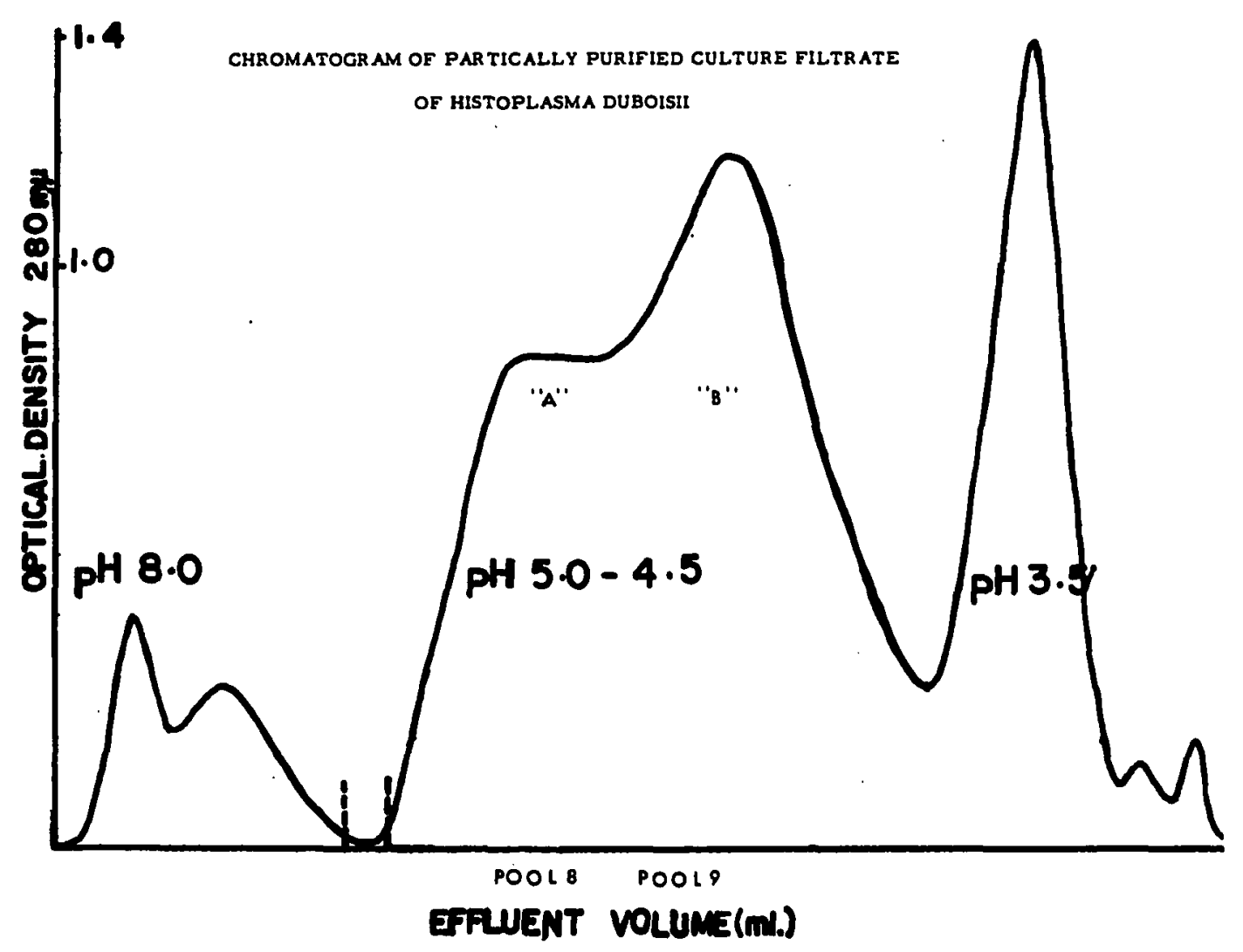

Fig. 5.--Chromatogram of partially purified culture filtrate of Histoplasma duboisii. 
when examined by Ouchterlony technic (31) and immunoelectrophoresis. (1) (Fig. 4D) Also, immuno-electrophoretic test of pool 9 (Fig. 5) and "m" antigen of Schubert (17) show that they migrate differently. (Fig. 4E)

\section{Antigen Potency as Affected by Culture Age}

Variation was found in the different age culture of the 2 strains of $\underline{H}$. duboisii studied. Both show an increase in activity as a skin test antigen during a six month incubation period. However, the antigen of $\underline{H}$ duboisii 210 showed a less potency as a skin test antigen than that of $\underline{H}$. duboisii 2100 (Fig. $7 \&$ 9). The mean erythema and induration at 4 weeks of $\underline{H}$. duboisii 210 were $4 \mathrm{~mm}$ and $4 \mathrm{~mm}$ respectively while for $\underline{H}$. duboisii 2100 were $5 \mathrm{~mm}$ and $5 \mathrm{~mm}$ respectively. At 6 months the mean erythema and induration were 13,10 respectively for $\underline{H}$. duboisii 210 and $(16,15)$ for H. duboisii 2100. However, there were several individual readings of $(25,20)$. There was no positive reaction for histoplasmin $\mathrm{H}-42(1: 25)$ on all animals infected with the two strains of $\underline{H}$ duboisij. No positive reaction was found in negative control animals. Table 8 .

As shown in Fig. 7 there was a significant increase in the skin test reaction from the two month old antigen of the undiluted crude material of $\underline{H}$. duboisii 210. A 1:2 dilution of the crude material gave a mean reaction below the generally accepted positive reaction size of $5 \mathrm{~mm}$ induration. 
However, a 1:10 dilution of the 4 months old resulted in a mean skin reaction of $9 \mathrm{~mm}$ erythema and $5 \mathrm{~mm}$ induration. Table 7 .

Figure 8 shows the changes in total protein, total carbohydrate and reducing sugars during the 6 month incubation period. In $\underline{H}$. duboisii 210 there was a gradual change in total protein with an increase from $5 \mathrm{ug} / \mathrm{ml}$ to $800 \mathrm{ug} / \mathrm{ml}$. Total carbohydrate decreased sharply from $38 \mathrm{mg} / \mathrm{ml}$ to $25 \mathrm{mg} / \mathrm{ml}$ after one month incubation, and decreased gradually to almost 0 at 6 months. The amount of reducing sugars remained the same until the fourth week, and then gradually decreased to almost zero at 6 months. The $\mathrm{pH}$ rises at 6 weeks from 6.2 to 7.8 at 5 months and remained relatively the same at 6 months. Fig. 10.

Figure 9 shows the skin test reactions to antigen produced by $\underline{H}$. duboisii 2100 . This culture followed a pattern similar to $\underline{H}$. duboisii 210 , only there is a sharp increase in potency from the 8 th week of incubation onward. In fact a 1:10 dilution of the 8 th week old crude material gave a mean reaction of $6 \mathrm{~mm}$ erythema and $5 \mathrm{~mm}$ induration; and reached a maximum of $25 \mathrm{~mm}$ erythema and $24 \mathrm{~mm}$ induration at 6 months. No positive reaction was seen with $\mathrm{H}-42$ histoplasmin. Twelve guinea pigs which were previously infected with $\underline{H}$. capsulatum HT-1 also gave negative readings to all the crude mycelial growth filtrates of $\underline{H}$. duboisii tested. Table 8. 


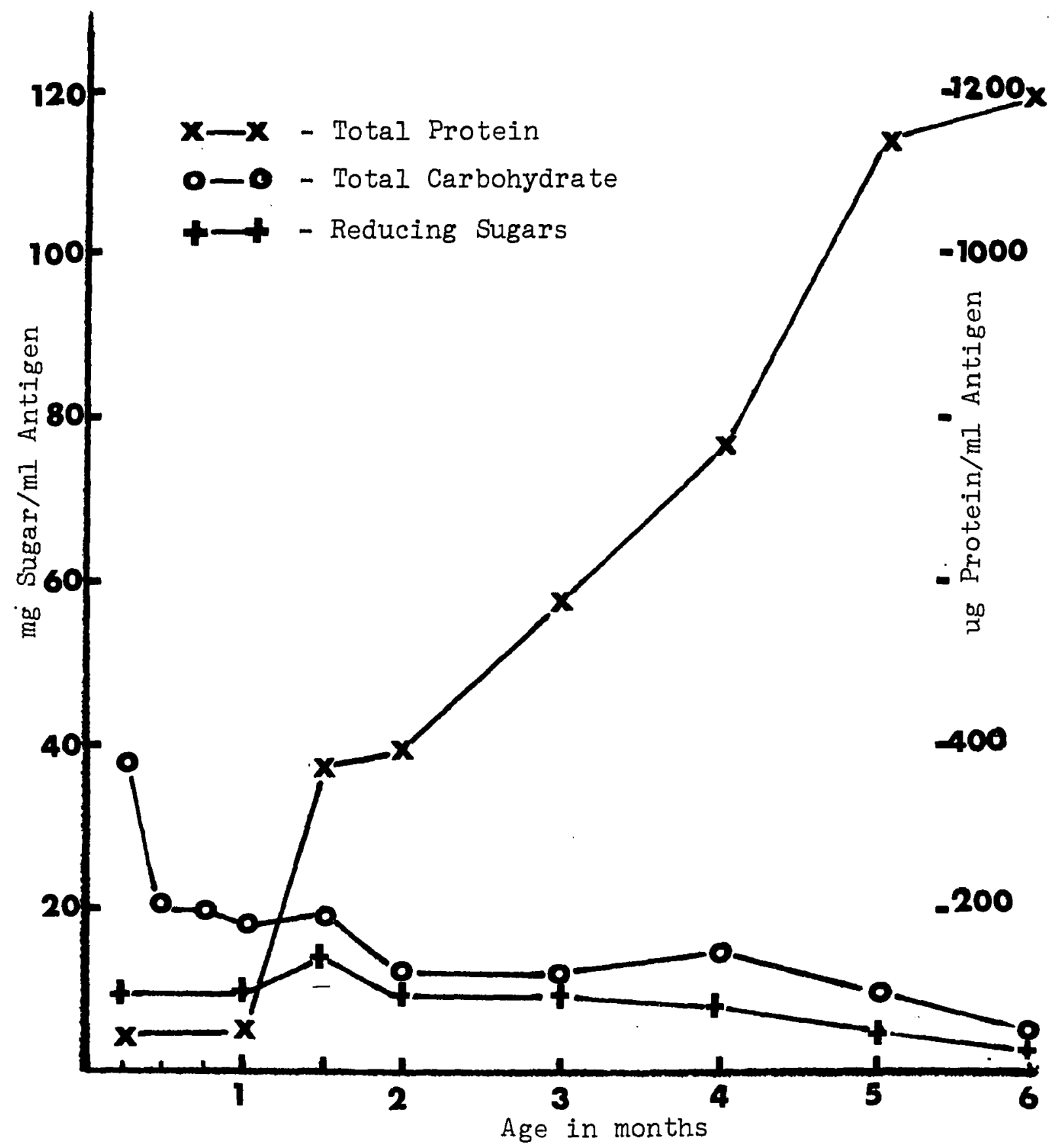

Fig. 6.--Changes in total protein, total carbohydrate, and reducing sugars during a 6 month incubation period of $\underline{H}$. duboisii 2100 . 


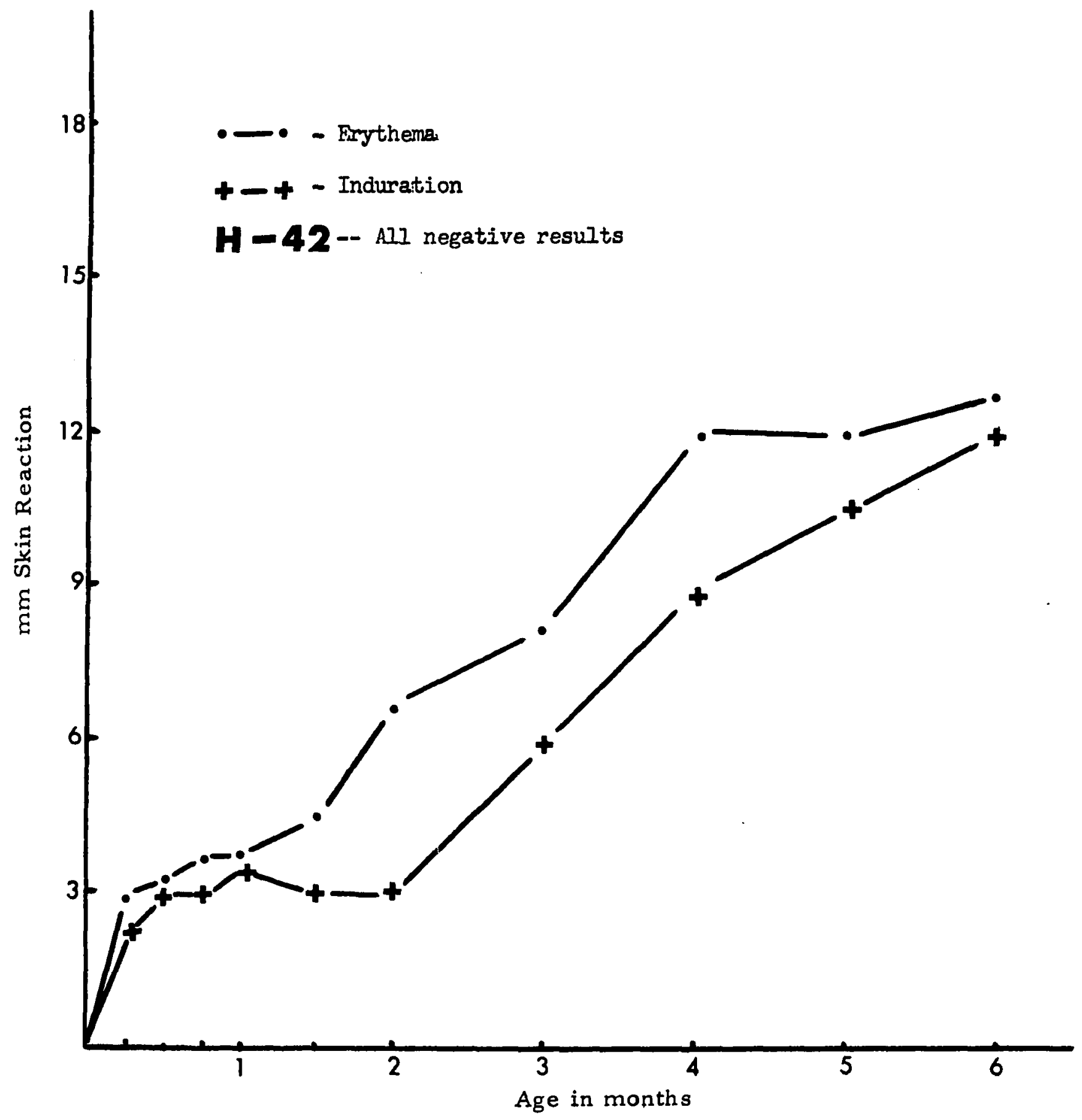

Figure 7.--Mean skin test reaction of crude mycelial filtrates of $\mathrm{H}$. duboisii 210 


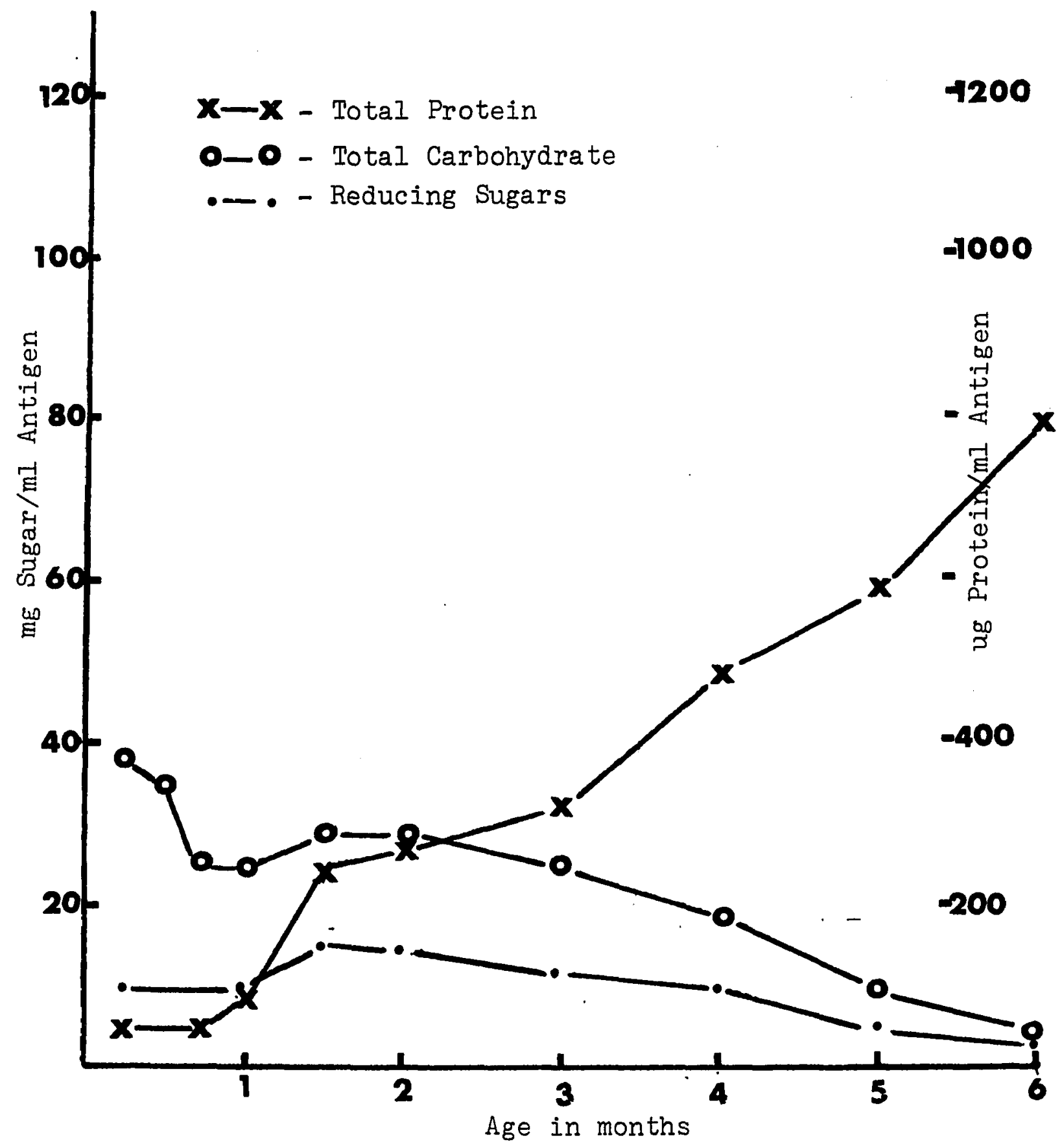

Fig. 8.--Changes in total protein, total carbohydrate, and reducing sugars during a 6 month incubation period of $\underline{H}$. duboisii 210 . 


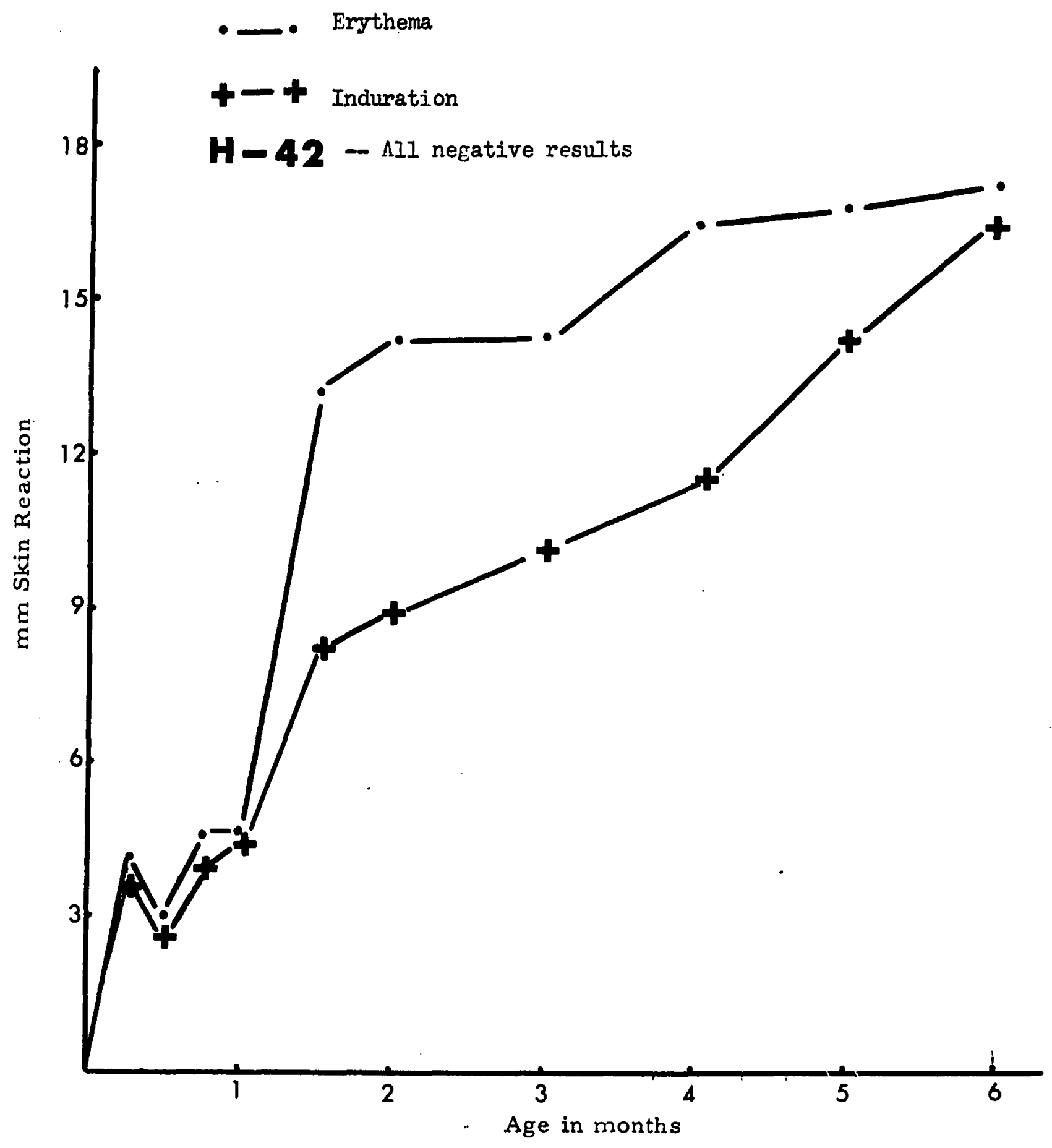

Figure 9. --Mean skin test reaction of crude mycelial filtrates of $\mathrm{H}$. duboisii 2100 


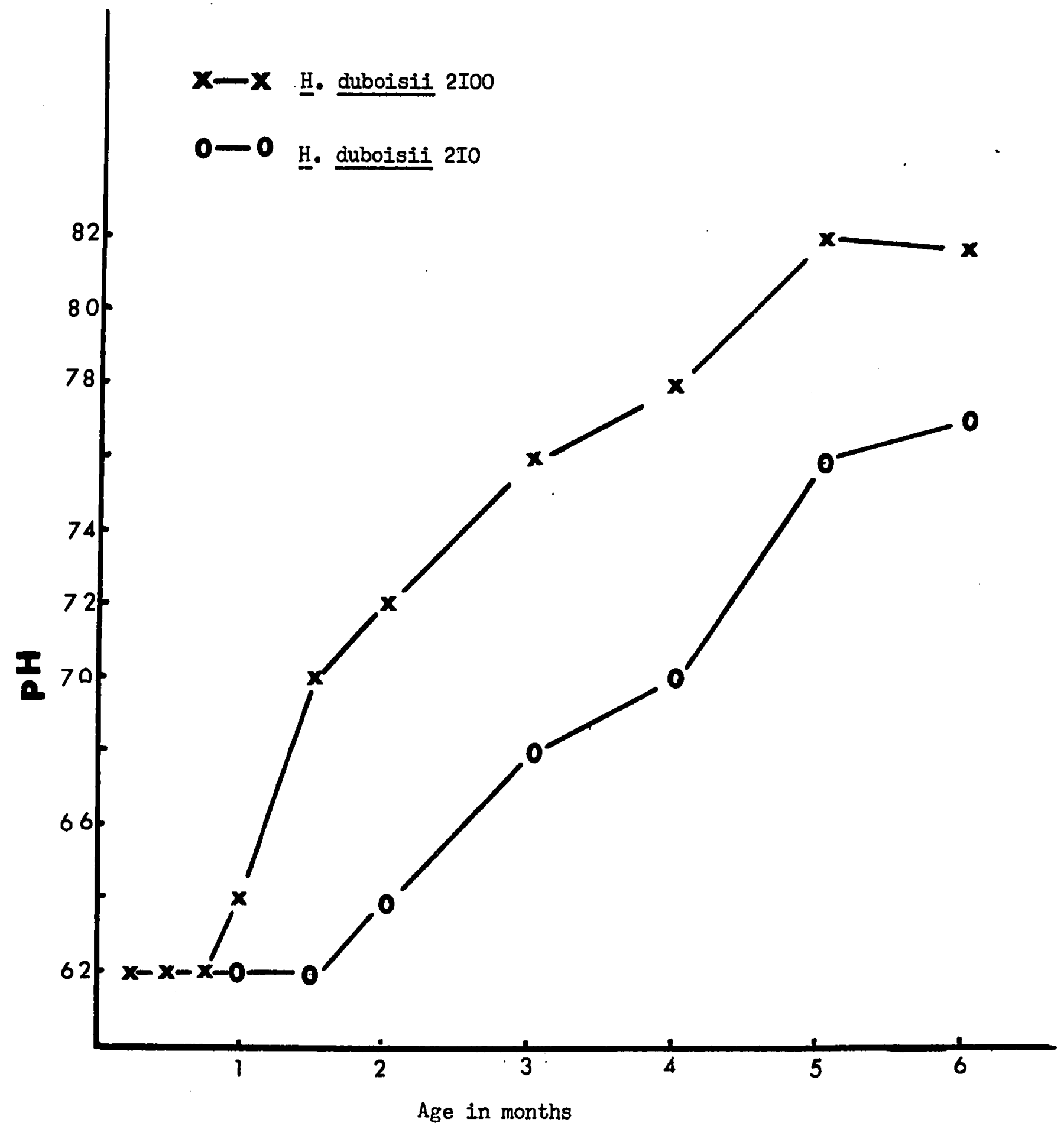

Figure IO-- pH readings of mycelial growth filtrates of H. duboisii $2 I 00$ and $\mathrm{H}$. duboisii $2 \mathrm{IO}$ 
TABLE 7.--Skin test results with different dilution of the crude filtrates

\begin{tabular}{|c|c|c|c|c|c|}
\hline \multirow[b]{2}{*}{ Crude Antigen } & \multirow[b]{2}{*}{$\begin{array}{c}\text { Age } \\
\text { (Weeks) }\end{array}$} & \multicolumn{4}{|c|}{ Dilutions } \\
\hline & & $1: 2$ & $1: 5$ & $1: 10$ & $1: 25$ \\
\hline H. duboisii 2100 & 1 & - & - & - & \\
\hline H. duboisii 2100 & 2 & - & - & - & \\
\hline H. duboisii 2100 & 3 & - & - & - & \\
\hline H. duboisii 2100 & 4 & - & - & - & \\
\hline H. duboisii 2100 & 6 & $+(8,5)$ & $+(7.4,5)$ & - & \\
\hline H. duboisii 2100 & 8 & $+(12,8)$ & $+(7.6,5)$ & $+(12,5)$ & \\
\hline H. duboisii 2100 & 12 & $+(10,6.2)$ & $+(12,7 \cdot 3)$ & $+(10,6.8)$ & \\
\hline H. duboisii 2100 & 16 & $+(12,7.6)$ & $+(11,7 \cdot 5)$ & $+(12,9.6)$ & \\
\hline H. duboisii 2100 & 20 & $+(15,12)$ & $+(12,10)$ & $+(10,8)$ & \\
\hline$\underline{H} \cdot \underline{\text { duboisii }} 2100$ & 24 & $+(15,14)$ & $+(13,12)$ & $+(11,9)$ & \\
\hline H. duboisii 210 & 1 & - & - & - & \\
\hline H. duboisii 210 & 2 & - & - & - & \\
\hline H. duboisii 210 & 3 & - & - & - & \\
\hline H. duboisii 210 & 4 & - & - & - & \\
\hline
\end{tabular}


TABLE 7.--Continued

\begin{tabular}{|c|c|c|c|c|c|}
\hline \multirow[b]{2}{*}{ Crude Antigen } & \multirow[b]{2}{*}{$\begin{array}{c}\text { Age } \\
\text { (Weeks) }\end{array}$} & \multicolumn{4}{|c|}{ Dilutions } \\
\hline & & $1: 2$ & $1: 5$ & $1: 10$ & $1: 25$ \\
\hline H. duboisii 210 & 6 & - & - & - & \\
\hline H. duboisii 210 & 8 & 8 & - & - & \\
\hline H. duboisii 210 & 12 & $+(5,5)$ & - & - & \\
\hline H. duboisii 210 & 16 & $+(12,7)$ & $+(9,5)$ & $+(9,4)$ & \\
\hline H. duboisii 210 & 20 & $+(11,8)$ & $+(10,6)$ & $+(7,7)$ & \\
\hline H. duboisii 210 & 24 & $+(13,10)$ & $+(10,9)$ & $+(8,7)$ & \\
\hline $\mathrm{H}-42$ & & & & & - \\
\hline
\end{tabular}


TABLE 8.--Skin Test Reactivity to Homologous and Heterologous Antigens

\begin{tabular}{lccc}
\hline & \multicolumn{3}{c}{ Antigens } \\
\cline { 2 - 4 } $\begin{array}{l}\text { Animals } \\
\text { infected with }\end{array}$ & $\underline{H} \cdot$ duboisii 2100 & $\underline{H} \cdot$ duboisii 210 & H-42 \\
\hline H. duboisii 2100 & $20 / 25^{*}$ & $20 / 25$ & - \\
H. duboisii 210 & $18 / 25$ & $18 / 25$ & - \\
H. capsulatum H-T1 & - & - & $10 / 12$ \\
Formalin killed & $12 / 25$ & $12 / 25$ & - \\
H. duboisii 210 & - & - & - \\
Control group & - & & - \\
\hline
\end{tabular}

*No. of animals of total that gave a positive skin test reaction. 
Results of chemical determinations performed on the crude filtrates material produced by $\underline{H}$. duboisii 2100 is shown in Fig. 6. The total protein remained relatively stable the first month, then began a steady increase in concentration in 8 week old culture to $1,200 \mathrm{mg} / \mathrm{ml}$ at 6 months. The total carbohydrate decreased from $38 \mathrm{mg} / \mathrm{ml}$ to $20 \mathrm{mg} / \mathrm{ml}$ at 3 weeks, decreased further to $18 \mathrm{mg} / \mathrm{ml}$ at 4 weeks, then increased slightly to $20 \mathrm{mg} / \mathrm{ml}$ at $11 / 2$ months, and decreased to $12 \mathrm{mg} / \mathrm{ml}$ at 2 months, and then gradually decreased to almost 0 at 6 months. The reducing sugar concentration remained the same throughout the 1 st 4 weeks, then increased at 8 weeks to $5 \mathrm{mg} / \mathrm{ml}$ and decreased to $8 \mathrm{mg} / \mathrm{ml}$ at 2 months and gradually decreased to almost 0 at 6 months. The pH rises at 3 weeks from 6.3 to 8.2 at 5 months, and decreased slightly at 6 months. (Fig. 10) Hyperimmunized Animals.--25 guinea pigs were hyperimmunized with formalin killed mycelial fragments of $\underline{H}$. duboisil 210 and were skin tested to crude mycelial filterate of $\underline{H}$. duboisil 210 and $\underline{H}$. duboisil 2100. There were skin reactions, but much lower than those of the infected animals. Six weeks old antigen elicit the same skin reactions as the 4 month old antigen with a mean of $8 \mathrm{~mm}$ erythema and $6 \mathrm{~mm}$ induration. There were no skin reactions to histoplasmin $\mathrm{H}-42$ in this group. 
Evaluation of Serological Test

It was observed that the C. F. titers of sera from H. duboisii infected and hyperimmunized animals to histoplasmin H-42 range from 1:8 to $1: 256$ and in one case as high as $1: 512$.

Evaluation of Acrylamide Disc

Gel Electrophoresis

To determine the reproducibility of this method, initial studies were performed; and on several occasions aliquots of lypholized samples were electrophoresed. Visual observations indicated good reproducibility. Densitometer tracings of the columns also were in agreement with each other.

Characterization of lypholized crude mycelial growth filtrate has been accomplished using acrylamide gel electrophoresis. (27). All samples subjected to electrophoresis in this study were used several times. Fig. 11 represents the gel columns of the crude mycelial growth filtrates of H. duboisii 210 and their corresponding microdensitometer tracings. One, two, three, and four weeks old antigens showed only one band $(\operatorname{Rf} .5)$. At 6 weeks one additional band ( $R f .46$ ) appeared. The 8 week old antigen exhibited several bands of which 8 were very distinct. One band ( $R f .74$ ) was very outstanding with regards to the density. However, at 12 weeks, another band ( $\operatorname{Rf} .66$ ) became more prominent while most of the bands ( $\operatorname{Rf} .24, .44$ and .36) 


$$
44
$$

gradually disappeared. Similar electrophoretic patterns were observed at 16 and 20 weeks (Fig. 14). However, the densities of the bands were much greater in the 20 week old antigen than the 16 week old. Two bands ( $R f .16, .36$ ) appeared and became prominent at 20 weeks. Band $(\operatorname{Rf} .5)$ has the greatest density at both ages. However, 24 week old crude material showed a much increased density in bands ( $\operatorname{Rf} .16$ and .36), while band ( $\operatorname{Rf} .46)$ became slightly higher in density. Fig. 14

Fig. 12 represents the gel columns of the crude mycelial growth filtrates of $\underline{H}$. duboisii 2100 and their corresponding microdensitometer tracings. Similar to $\underline{H}$. duboisii 210, the 1-4 weeks old crude filtrate showed only one band ( $\mathrm{Rf} .5$ ) each, but at six weeks, there were 5 bands of which 2 bands ( $\operatorname{Rf} .16 \& .36$ ) showed great densities. The 8 week old showed one more additional band ( $\mathrm{Rf} .46$ ), while the 12 week old showed a marked decrease or gradual disappearance with time of a band $(\operatorname{Rf} .16)$. The band ( $\operatorname{Rf} .36)$ remained high in density through the 16th week (Fig. 13). At 20 weeks the electrophoretic pattern of the crude filtrates followed closely that of the 16 weeks old crude filtrates with much increased density. The band ( $R f .36$ ) remained prominent. The 24 week old crude filtrates exhibited the following pattern: band ( $R f .16)$ which reappeared at 20 weeks became more evident while band ( $R f .36$ ) increased and remained greatest in density from the 6 th week onward. Fig. 13 

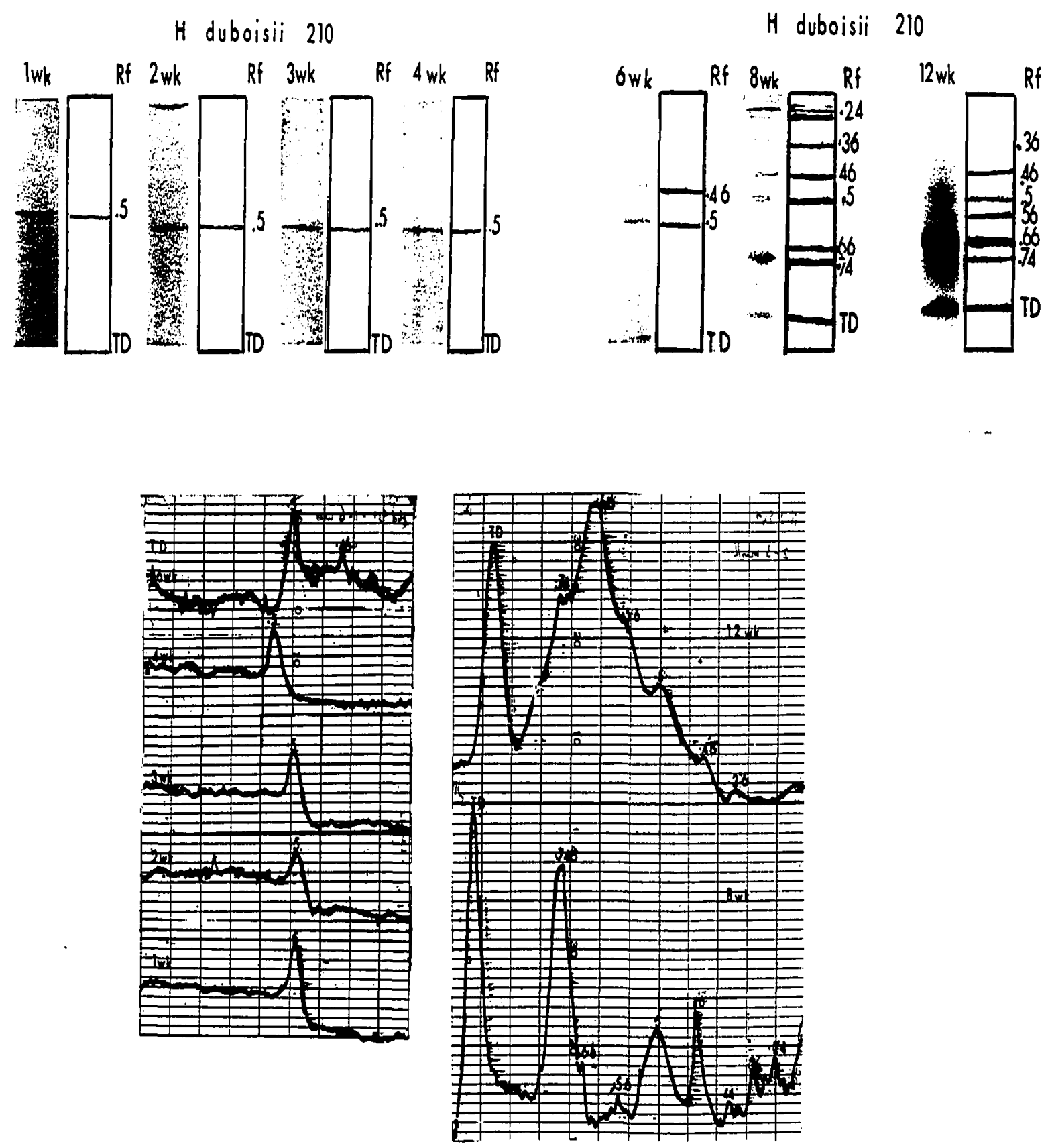

Fig. 11,--H. duboisii 210. Electrophoretic pattern in acrylamide gel from culture filtrate. 
$H \cdot$ duboisii 2100

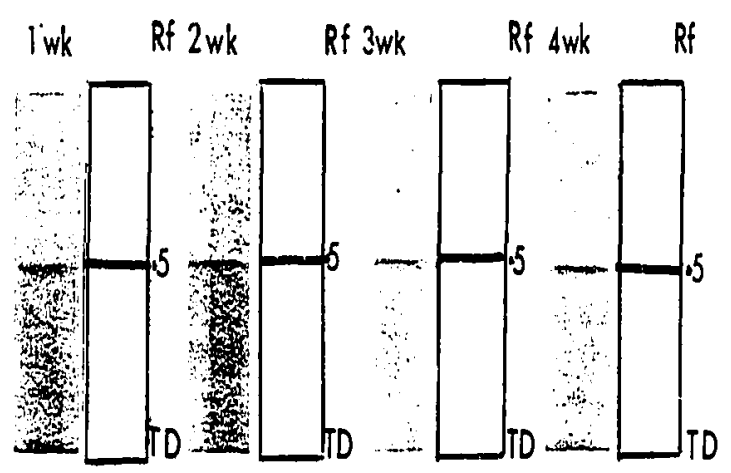

$H \cdot$ duboisii 2100

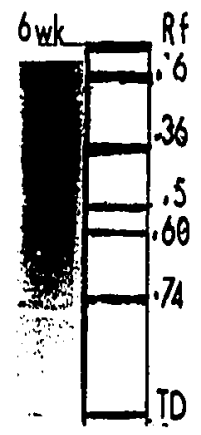

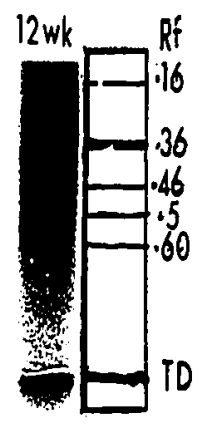
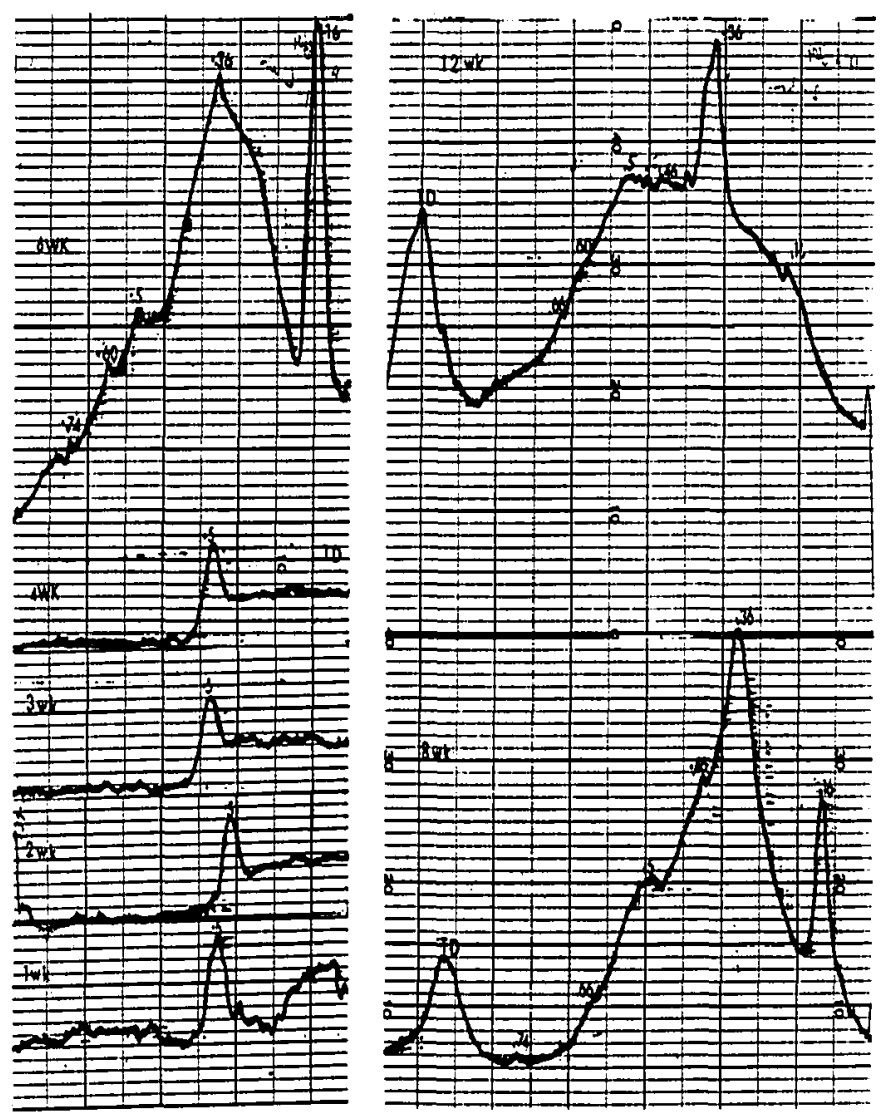

Fig. 12.--H. duboisii 2100. Electrophoretic pattern in acrylamide gel from culture filtrate. 
$H \cdot d u b o i$ sii 2100

Amido Black
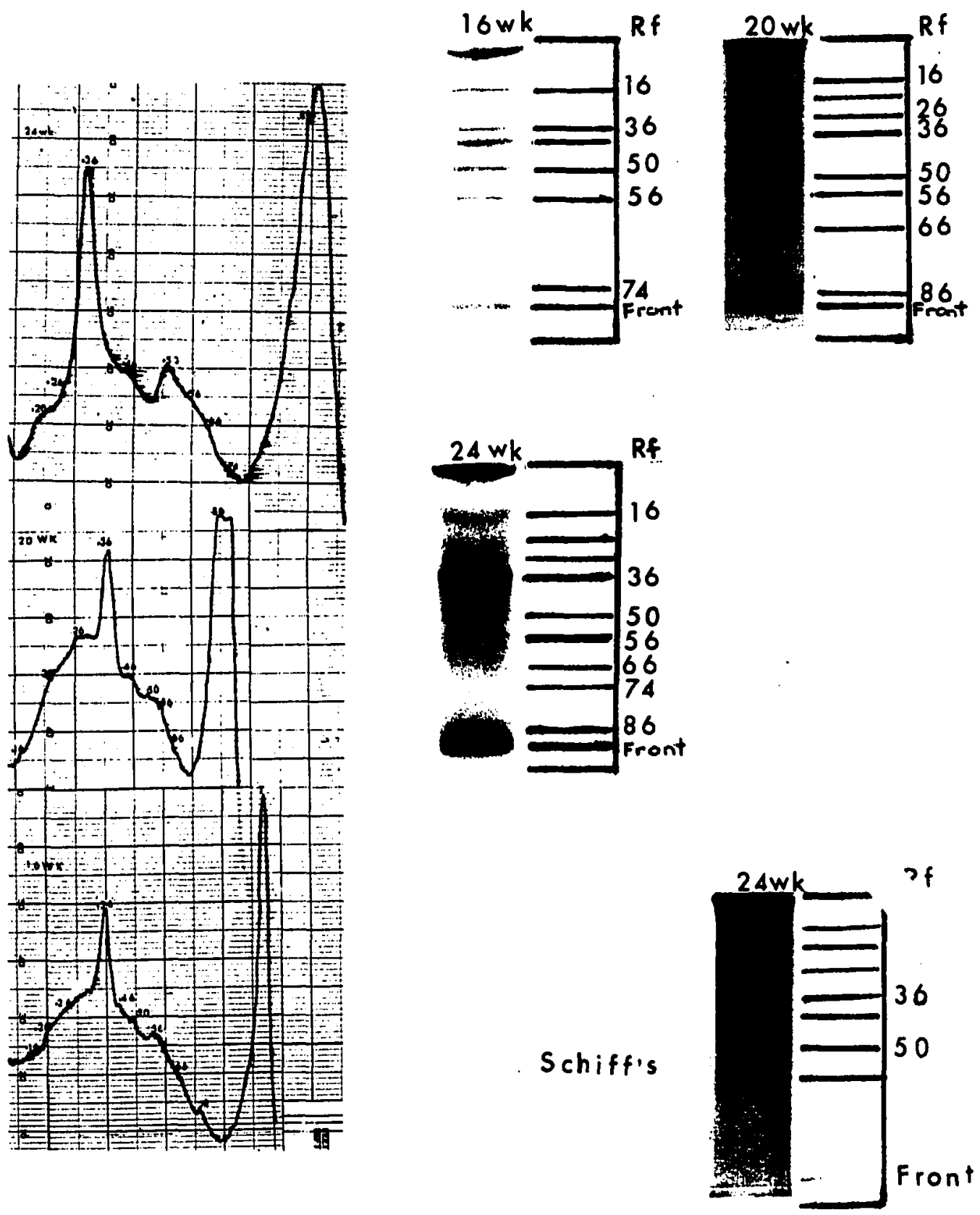

Fig. 13.--H. duboisii 2100. Electrophoretic pattern in acrylamide gel from culture filtrate. 


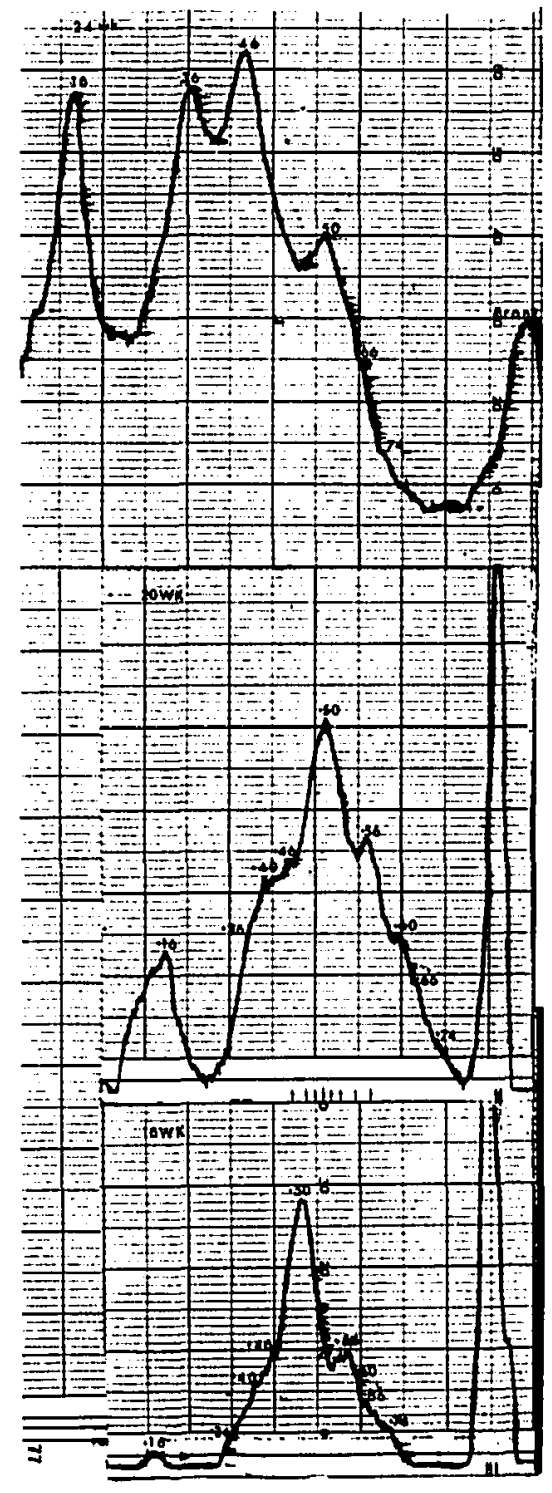

$H$ duboisii 210

Amido Black
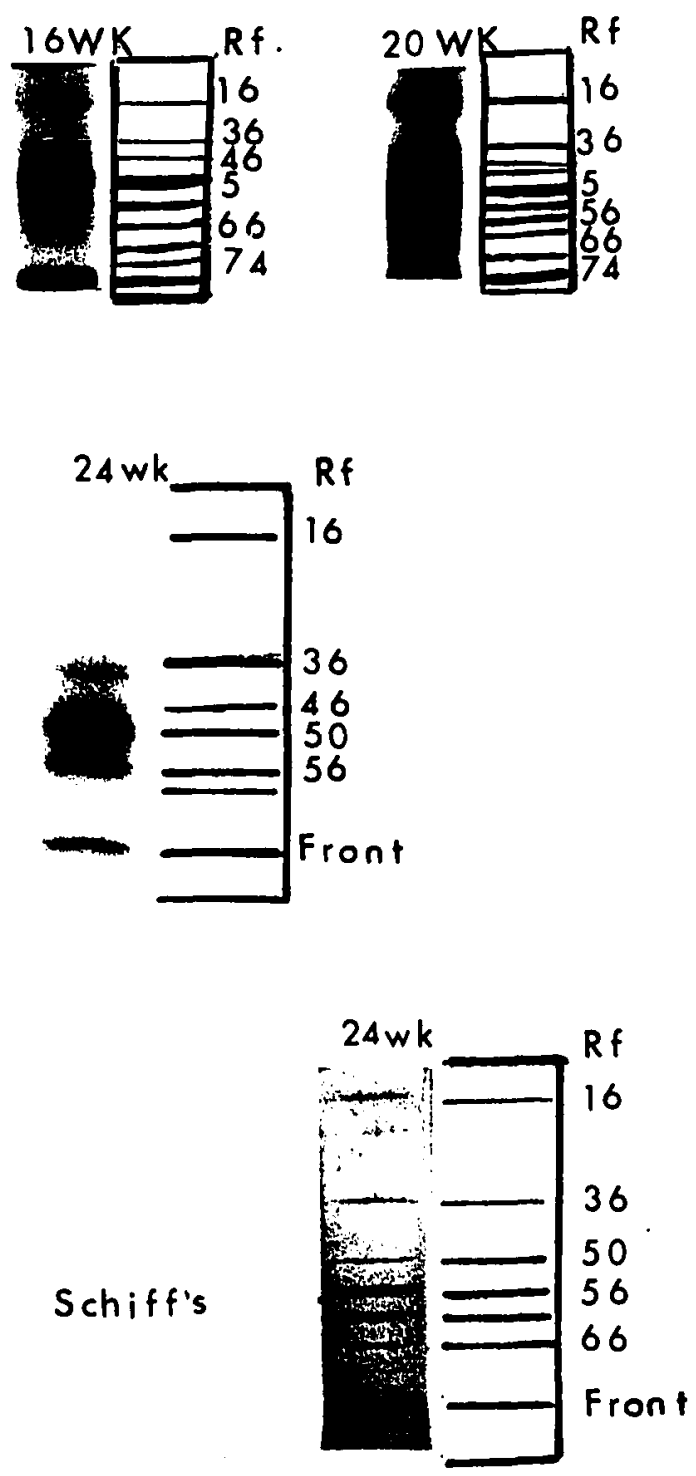

Fig. 14.--H. duboisii 210. Electrophoretic pattern in acrylamide gel from culture filtrate. 


\section{DISCUSSION}

A total lack of epidemiological investigations of H. duboisii infections have provided the impetus for research of $\underline{\mathrm{H}}$ duboisii crude mycelial antigens and its role in the detection of infection allergy. Presented in this paper is evidence that shows how crude mycelial filtrate of H. duboisii is specific in the detection of infection allergy due to $\underline{H}$. duboisii infections.

Previous studies on the infection of mice and hamster with $\underline{H}$. duboisii have demonstrated variation in virulence of this organism. Schwarz et al. (41) and Depoux et al. (12) reported that neither hamsters nor mice died from intraperitoneal injection of large doses of culture suspension of one isolate of $\underline{\mathrm{H}}$. duboisii. However, the lack of virulence was not a definite characteristic for isolates from African Histoplasma. Earlier, Drouhet (13) reported that two isolates which were isolated from African Histoplasma with large cells were lethal to mice and hamster on intraperitoneal injection. Also in this study, all isolates used were lethal to guinea pigs by intraperitoneal injection. All showed, in male guinea pigs, peculiar characteristics of severe orchitis and gradual involvement of the organs of RES. 
This suggests a relationship of sex to resistance of guinea pigs to experimental $\underline{H}$. duboisii infections or a relationship of male sex hormones to the cultivation of yeast cells of $\underline{H}$. duboisii. (25)

Animal infection studies suggest several factors were influential and contribute to the apparent variation of results frequently obtained. Growth phase of the organisms, route of inoculation, size of inoculum and viability of specific isolates must be considered when one attempts to characterize the sensitizing agent. (3). In this study, the mycelial and yeast phases were used with intraperitoneal injection of heavy doses. Mortality occurred earlier in those infected with yeast cells, which may be due to the fact that mycelial fragments had to convert to the yeast cells prior to inducing lethal infections. Secondly, the infection provided materials for microscopic study in which the morphology of the cells and occurrence in RES organs could be studied. The role of the lymphatics was seen earlier in the course of infection because while the lymph nodes were all full of yeast cells, only in isolated spots in the liver, lungs, spleen and kidney, were one able to find yeast cells. Most cells were round or slightly ovoid and had two thick walls, which were rather refractile in hemotoxylin and eosin preparations and which stained uniformly dark brown with methaneamine silver. The cells were large (13u) and were budding yeast cells. 
The preliminary immunological findings in these studies were significant. In spite of long standing infection, the humoral antibody response as detected by C. F. technique is Iight, with one exception (C. F. titer 512), while the cellular response as detected by skin-test to crude mycelial filtrate, was more sensitive. Also, during active immunization with formalin killed mycelial fragments the reverse situation prevails. Seemingly, any possible explanation of these observations would suggest that the induction of skin sensitivity depends upon the presence of living organisms in the body, while the presence of antibodies would be correlated to the concentration of antigens released within the body, or introduced from outside. However, it would be understandable to conceive that in infections due to such slow growing organisms, and the early involvement of the lymphatics and later involvement of other organs of RES, the amount of antigen released may be insufficient to lead to significant antibody formation. On the other hand, if hyperimmunization procedure were followed, demonstrable antibody formation was evident.

The partial purification and separation of specific antigens of the crude mycelial filtrates of $\underline{H}$. duboisij was accomplished in this study. "A" and "B" antigens (15) of H. douboisii can be separated from each other by column chromotography in DEAE-Sephadex. "A" and "B" antigens of H. duboisii functioned similarly as "H" and "M" antigens of 
52

H. capsulatum in that "A" antigen appears later during infection and was specific for active histoplasmosis while "B" antigen appeared earlier and was specific for delayed hypersensitive reaction in infected animal. It was not, however, demonstrated that "A" and "B" antigens of $\underline{\mathrm{H}}$. duboisii and "B" and "M" antigens of $\underline{H}$. capsulatum $(1,39,40)$ have common identity. The "B" antigen apparently specific for delayed hypersensitive reaction did not immunoelectrophorese similarly with "M" antigen of $\underline{H}$. capsulatum. However, it appears that $\underline{H}$. capsulatum and $\underline{H}$. duboisii have at least one antigen in common. These observations were further strengthened by the fact that Histoplasmin $\mathrm{H}-42$ $(1: 25)$ did not elicit any skin reaction on $\underline{H}$. duboisii infected animals, but $\mathrm{H}-42$ reacts with $\mathrm{C}$. F. antibodies of H. duboisii infected animals. Also, animals infected with H. capsulatum did not elicit any skin reaction with $\underline{H}$. duboisii crude mycelial growth filtrates. This might suggest that "B" and "M" antigens were distinctively different and that "A" and "H" antigens, at least have similar specifities or common identities. Kaufman et al. also have reported close antigenicity relationship of $\underline{H}$. capsulatum to $\underline{H}$. duboisii (20).

The evidence now available makes it appear that $\underline{H}$. duboisii in its biochemical behavior in synthetic medium closely resembles $\underline{H}$. capsulatum and many other parasitic fungi. It has a relatively low metabolic rate and under 
optimal cultural conditions grows slowly. The mycelial form of the fungus has but moderately exacting requirements which were easily satisfied by providing a simple organic source of carbon, an inorganic source of nitrogen and traces of growth factors. Considerable variation exists in supporting media, physical growth conditions and harvesting age for production of histoplasmin (47). The crude mycelial growth filtrates used in these investigations were produced in Smith's Asparagine medium (45), which contains the amino acid asparagine as the only organic source of nitrogen. Salvin and Hottle reported that maximal yield of histoplasmin in a glucose asparagine medium was obtained after 2 to $21 / 2$ months of growth at room temperature (34). In this study, the skin reaction inducing material appear as early as $11 / 2$ months in one isolate and 3 months in the other. This is paralleled by a rise in alkalinity to $\mathrm{pH} 8.2$ and above, a drop in reducing sugars to almost zero, and a rise in total protein. This might suggest the conversion of glucose to such as the structural component chitin and possibly skin test active material ( 47 ).

The rise in $\mathrm{pH}$ of the mycelial growth filtrates with age would indicate that nitrogen compounds were simultaneously attacked with the formation of ammonia. This was enhanced by the presence of glucose. In the medium, asparagine was the sole source of organic nitrogen. Asparagine, the B-amide of aspartic acid produces ammonia 
54

during acidic and alkaline hydrolysis, giving rise to aspartic acid (49). Hence, a large part of the ammonia liberated as the medium changes from acid to alkaline, was probably used in the synthesis of protoplasm and skin-test active materials. A nitrogen free precursor, probably carbohydrate derivative, which can combine readily with ammonia would be required to bring this about as a result of some metabolic activities yet undefined. Results of this study show that all bands which stained with amido black, signifying protein, also stain with Schiff's which signifies carbohydrate. This indicates that the material was a protein-carbohydrate complex, probably glycoprotein. A similar result has been reported for $\underline{H}$. capsulatum crude mycelial growth filtrates $(47,48)$.

It is conceivable that $\underline{H}$. duboisi ${ }^{\prime}$ was able to split oif from asparagine molecule both the amide and amino nitrogen to produce ammonia. This would probably indicate the presence of at least two enzymes, simultaneously operative in bringing about nitrogen decomposition of the asparagine molecule in the medium. The presence of amidase, in mycelial growth medium of $\underline{H}$. capsulatum had been demonstrated, and it was suggested that aminase was probably present also. The cultures were started at pH 6.2 , hence aminase would be presumed predominant at first because aminase is most active at slightly acid reaction, but as soon as sufficient ammonia is produced to shift the reaction 
to alkaline side amidase takes over (38). There was probably some overlapping between the two enzymes, however, both lead, in the final analysis, to ammonia formation. Another possible mechanism which might cause the same effect, may be an oxidation to the corresponding $\mathrm{x}$-ketonic acids, with the production of ammonia at the same time $(38,21)$. In the case of asparagine the extent of oxidative deamination would be limited to one-half of its molecular nitrogen content.

The electrophoretic patterns show that there were only quantitative differences of the carbohydrate-protein complex between the two isolates with regards to the culture age. Similar carbohydrate-protein complex bands most especially band $(\operatorname{Rf} .16, .36)$ and which seem to correlate with skin-test reactivity, were exhibited by both isolates but appear at different times during the growth period. These bands ( $\operatorname{Rf} .16, .36)$ appeared early ( 6 weeks) in the electrophoretic pattern of the mycelial growth filtrate of $\underline{H}$. duboisii 2100, and appear later (16 weeks) in $\underline{\mathrm{H}}$. duboisii 210. A similar situation existed in the production of protein, total carbohydrate and reducing sugars. There was an early rise or increase in the protein, ( 4 weeks) in the mycelial growth filtrate of $\underline{H}$. duboisij 2100, while a substantial rise in protein occurs as late as 8 th week in $\underline{H}$. duboisii 210. The total carbohydrate and reducing sugars show an early gradual decrease at 12 weeks. A similar 
picture was seen with $\underline{H}$. duboisii 210 except the gradual decrease did not occur until the 3rd month. Also, this corresponds to the rise in $\mathrm{pH}$ of both mycelial growth filtrates, and to the increase in potency as a skin test antigen.

Since 18 day old cultures of both organisms were inoculated initially, an explanation of this phenomenon could be the difference in the inoculum size and \% viability. H. duboisii 2100 has a \% viability of 3.4 and the inoculum size slightly more than that of $\underline{\mathrm{H}}$. duboisii 210. Hence, the more viable fragments present, the greater the total metabolic activity.

In essence, the result of this study, in general, was consistent with the conventional taxonomic classification of these isolates. This was demonstrated by the homologous bands exhibited by the electrophoretic patterns of the mycelial growth filtrates and biochemical characteristics. However, the difference between the skin test reactions of $\underline{H}$. duboisii and $\underline{H}$. capsulatum mycelial growth filtrates as shown in this investigation emphasized further, Vanbreuseghem's consideration of $\underline{H}$. duboisii as a new species of Histoplasma. 
A controlled environmental study has been conducted on the crude mycelial growth filtrate (1-24 week old) of 2 isolates of Histoplasma duboisii with regard to the biochemical characteristics and skin test antigen potency. A further investigation would be conducted on 12 months and 18 months old crude filtrates.

Evidence presented in this paper indicated that mycelial growth filtrate of $\underline{H}$. duboisii was specific for the detection of infection allergy due to $\underline{H}$. duboisii. However, $\mathrm{H}-42$, the mycelial filtrate of $\underline{H}$. capsulatum, gave a complement fixation reaction with serum of guinea pigs infected with $\underline{H}$. duboisii. Immuno-electrophoretic studies also indicated $\underline{H}$. duboisi $i$ and $\underline{H}$. capsulatum have at least one antigen in common, but the "M" antigen of $\underline{H}$. capsulatum specific for skin test reaction electrophoresed differently from the "B" antigen of $\underline{H}$. duboisii also specific for skin test reaction. The crude mycelial growth filtrate may be fractionated by Ion-Exchange chromatography resulting in partial purification of the skin test active material.

Data obtained from the 6 month controlled study of the crude mycelial growth filtrate of $\underline{H}$. duboisii indicated 
no optimal time for harvesting mycelial growth filtrate that will give a standard skin test reaction to homologously infected guinea pigs, but that the formation of active material may be related to the biochemical changes in the medium: increasing skin test potency with increasing total protein, and decreasing total carbohydrate and reducing sugars; and a rise in $\mathrm{pH}$. The electrophoretic data suggested that there was a great similarity between the two isolates studied, and the staining capability of the bands to Amido Black and Schiff's reagent suggested that the component is a proteincarbohydrate complex presumably a glyco-protein. The characteristic development of severe orchitis in the infection of male guinea pigs upon intraperitoneal injection of large doses of both mycelial fragments and yeast cells of $\underline{H}$. duboisii was also observed in this study. 


\section{BIBLIOGRA PHY}

1. Adamson, D. M., and G. C. Cozad, 1966. Immunoelectrophoretic studies of sera from rabbits experimentaily infected with Histoplasma capsulatum. J. Bacteriol. vol. 92, No. 4 887-891.

2. Ajello, I., Georg, L. K., Kaplan, W., and L. Kaufman, 1963. Laboratory Manual for Medical Mycology. C. D. C.

3. Bartels, P. A. 1968. Immunological response by guinea pigs chronically infected with Histoplasma capsulatum. (Dissertation) University of Oklahoma.

4. Berliner, Martha D. 1967. Gelatin hydrolysis for identification of the filamentous phase of Histoplasma, Blas tomyces, and Chrysosporum species. Sabouraudia 5 (4) $274-277$.

5. Blumer, S., Kaufman, L., and L. Ajello, 1957. Use of fluorescent antibodies to differentia te Histoplasma capsulatum from other yeast-like pathogens. Bacteriological Proceedings. M49.

6. Carnegie, P. R. 1965. Estimation of molecular size of peptides by gel filtration. Biochem. J. 95:9.

7. Cockshot, W. P., and A. O. Lucas, 1964. Radiological findings in Histoplasma duboisii infection. $\mathrm{Br} . \mathrm{J}$. Radio1. 37(441), 653-660.

8. Coresmeous, J. 1964. A biochemical test for differentiation of Histoplasma duboisii and Histoplasma capsulatum. C. F. Soc. Biol. Paris 157 (5) 11301132 .

9. Coudert, J., and M. Coly, 1956. Essai d'application de la reaction d'agglutination des particles de collodion a quelques parasitoses. Ann. Parasitol. Humaine et Comparee. 31, 489. 
10. Cozad, G. C., and Howard W. Larsh, 1960. A capillary tube agglutination test for Histoplasmosis. J. Immunol 85: 387-390.

11. Darling, S. T. 1906. A protosoan general infection producing pseudo-tubercles in the lungs, and focal necrosis in the liver, spleen, and lymph nodes. J. Amer. Med. Assoc., 46: 1283.

12. Depoux, R., P. Merveille, 1957. L'Histoplasmose en A. E. F., Semaine Hop. Paris.

13. Drouhet, E. 1957. Quelques aspects biologiques et mycologiques de I'histoplasmose. Semaine hop. Paris.

14. Drouhet, E., and J. Schwarz, 1956. Comparative studies with 18 strains of Histoplasma. Morphology in tissues and virulence of African and American strains. J. Lab. Clin. Med. 47, 128-139.

15. Fadulu, S. 1965. Comparative study of Histoplasmin from Histoplasma duboisii and Histoplasma capsulatum. (Thesis). University of Oklahoma.

16. Furcolow, M. I. 1960. Clinical types of Histoplasmosis. Charles C. Thomas. Springfield, Illinois, 382-404.

17. Goodman, N. L., Sprouse, R. F., and Howard W. Larsh, 1968. Histoplasmin potency as affected by age. (Accepted for pub. in Sabouraudia 1968).

18. Greene, C. H., Delalla, L. S., and V. N. Tompkins, 1960. Separation of specific antigens of Histoplasma capsulatum by Ion-Exchange chromotography. Proc. Soc. Exper. Biol. \& Med. 105, 140-141.

19. Heiner, D. C. 1958. Diagnosis of Histoplasmosis using precipitin reaction in Agar-gel. Ped. 22, 616-627.

20. Kaufman, L., and S. Blumer, 1966. Occurrence of Serotypes among Histoplasma capsulatum strains. J. Bacteriol. vol. 91, No. 4, 1434-1439.

21. Krebs, H. A. 1933. Oxidation of Amino Acids. Ztschr, f. physiol. Chem., 217, 151.

22. Lackman, D. B. 1957. National Institute of Health Circular No. 12. Revised. 
23. Larsh, Howard W., and M. L. Furcolow, 1956. Follow-up of the Camp Gruber epidemic in U.S. Dept. of H.E.W. Proc. of the conference on His toplasmosis. Pub. Health Monogr. No. 39: 34-38.

24. Long, D. W. 1959. A comparative study of Histoplasmin produced under various environmental conditions. (Masters Thesis). University of Oklahoma.

25. Loosli, G. G. 1955. Histoplasmosis: Some clinical, epidemiological and laboratory aspects. Med. Clin. North America 39: 171-199.

26. Loosli, G. G., Beadenkopf, W. G., Rice, F. A., and L. J. Savage, 1951. Epidemiological aspects of histoplasmin, tuberculin, and coccidioidin sensitivity. Am. J. Hyg. 53: 33-57.

27. Lowry, O. H., Rosebrough, A. L., Farr, A. L. and R. J. Randall, 1957. Protein measurement with the Folinphenol reagent. J. Biol. Chem. 193: 265-275.

28. Markowitz, H. 1964. Polysaccharide antigen from Histoplasma capsulatum. Proc. Soc. Exper. Biol. \& Med. 115: 697-701.

29. McDearman, Sara C. 1962. A modified histoplasmin in the hemagglutation test for Histoplasmosis. Amer. J. Med. Tech. 28, 146-160.

30. Okudaira, M., and J. Schwartz, 1961. Infection with Histoplasma duboisii in experimental animals. Mycologia 53, 53-63.

31. Ouchterlony, 0. 1949. Antigen and antibody reaction in gels. Acta Pathol. Microbiol. Scand. 26: 507.

32. Ornstein, L. 1964. Disc electrophoresis--Background and Theory. Ann. New York Acad. Sci. 121: 321349 .

33. Pine, L., Drouhet, E., and G. Reynolds, 1964. A comparative morphological study of the yeast phases of Histoplasma capsulatum and Histoplasma duboisii. Sabouraudia vol. 3, Part 3: 211-224.

34. Salvin, S. B. and G. A. Hottle, 1948. Factors influencing His toplasmin formation. J. Bacteriol. 56: $541-546$. 
35. Salvin, S. B., and R. F. Smith, 1959. Antigen from the yeast phase of Histoplasma capsulatum. J. Inf. Dis. vol. $105,45-53$.

36. Saslaw, S., and C. C. Campbell, 1949. A collodion agglutination test for Histoplasmosis. Pub. Health Rep. 64: 424-429.

37. Saslaw, S., and J. Schaefer, 1955. Relation of sex and age of mice to experimental Histoplasma infections. Proc. Soc. Exper. Biol. \& Med. 90: 400.

38. Scheff, G. J. 1945. Biochemical and immunological properties of Histoplasma capsulatum. No. 650. Yale J. Biol. \& Med. 18: 41-54.

39. Schubert, J.H., and Iynch, H. J. Jr., and I. Ajello, 1961. Evaluation of the Agar-plate precipitin test for histoplasmosis. Amer. Rev. Resp. Dis. vol. 84, No. 6: 845-849.

40. Schubert, J.H., and G. L. Wiggins, 1965. Preliminary studies of $\mathrm{H}$ and $M$ components of Histoplasmin for skin test and serology. The Amer. Rev. Resp. Dis. vol. 92, No. 4: 640-641.

41. Schwartz, J., and E. Drouhet, 1957. Morphologic features of an African Strain of Histoplasma in hamsters and mice. A.M.A. Archives of Pathology $64,409-413$.

42. Scott, T. A., and E. H. Melvin, 1953. Determination of dextran with anthrone. Anal. Chem. 25: 1656.

43. Scott, V. 1955. Histoplasmin, coccidioidin, and tuberculin sensitivity in Honduras. The Amer. J. Trop. Med. 18: 41-54.

44. Shechter, Y., Landau, J. W., Dabrowa, Nina, and V. D. Newcomer, 1966. Comparative disc electrophoretic studies of protein from dermatophytes. Sabouraudia, vol. 5, Part 2: 144-149.

45. Smith, C. E. 1943. Coccidioidomycosis. Med. Clinics N. America 27: 790-807.

46. Somogyi, M. 1945. A new reagent for the determination of sugars. J. Biol. Chem. 160:61-68.

47. Sprouse, R. F. 1967. Chromatographic separation and isolation of skin test active components of Histoplasmin. (Dissertation. University of Okla.) 
48. Taha, B., and Howard W. Larsh, 1968. Disc electrophoretic patterns of mycelial growth filtrates of some parasitic fung1. Micro. dept (To be published).

49. White, A., Handler, P., and Emil L. Smith, 1964. Principles of Biochemistry. 3rd. Ed. McGraw-Hill Book Co.

50. Wiggins, G. I., and J. H. Schubert, 1965. Relationship of histoplasmin Agar-gel bands and complement

fixation titers in Histoplasmosis. J. Bacteriol. 89: $589-596$.

51. VanPernis, P. A., Benson, M. E. and P. H. Holinger, 1941. Specific cutaneous reaction with His toplasmin. J. Amer. Med. Assoc. 117: 436-437.

52. Vanbreuseghen, R. 1956. Histoplasma duboisii and large form of Histoplasma capsulatum. Mycologia 48, 264269.

53. Vanbreuseghen, R. 1953. Histoplasma duboisii and African Histoplasmosis. Mycologia. 45, 803-816.

54. Zarafonetis, C. J. D. and R. B. Lindberg, 1941. Histoplasmosis of Darling: Observations on the antigenic properties of the causative agent. Univ. Hosp. Bull., Ann Arbor 7: 47-48. 